\title{
BP180 Is Critical in the Autoimmunity of Bullous Pemphigoid
}

\author{
Yale $\mathrm{Liu}^{1+}$, Liang $\mathrm{Li}^{2+}$ and Yumin $\mathrm{Xia}^{1 *}$ \\ 'Department of Dermatology, The Second Affiliated Hospital, School of Medicine, Xi'an Jiaotong University, Xi'an, China, \\ ${ }^{2}$ National-Local Joint Engineering Research Center of Biodiagnostics and Biotherapy, The Second Affiliated Hospital, School \\ of Medicine, Xi'an Jiaotong University, Xi'an, China
}

\section{OPEN ACCESS}

Edited by:

Piotr Trzonkowski,

Gdańsk Medical University, Poland

Reviewed by:

Frank Antonicelli, University of Reims ChampagneArdenne, France

Angelo Valerio Marzano,

Università degli Studi di Milano, Italy

*Correspondence: Yumin Xia

xiayumin1202@163.com

tThese authors have contributed equally to this work.

Specialty section:

This article was submitted to Immunological Tolerance and Regulation,

a section of the journal

Frontiers in Immunology

Received: 17 October 2017 Accepted: 24 November 2017 Published: 08 December 2017

Citation:

Liu Y, Li L and Xia Y (2017) BP180 Is Critical in the Autoimmunity of Bullous Pemphigoid.

Front. Immunol. 8:1752. doi: 10.3389/fimmu.2017.01752
Bullous pemphigoid (BP) is by far the most common autoimmune blistering dermatosis that mainly occurs in the elderly. The BP180 is a transmembrane glycoprotein, which is highly immunodominant in BP. The structure and location of BP180 indicate that it is a significant autoantigen and plays a key role in blister formation. Autoantibodies from BP patients react with BP180, which leads to its degradation and this has been regarded as the central event in BP pathogenesis. The consequent blister formation involves the activation of complement-dependent or -independent signals, as well as inflammatory pathways induced by BP180/anti-BP180 autoantibody interaction. As a multi-epitope molecule, BP180 can cause dermal-epidermal separation via combining each epitope with specific immunoglobulin, which also facilitates blister formation. In addition, some inflammatory factors can directly deplete BP180, thereby leading to fragility of the dermal-epidermal junction and blister formation. This review summarizes recent investigations on the role of BP180 in BP pathogenesis to determine the potential targets for the treatment of patients with BP.

Keywords: BP180, bullous pemphigoid, autoantibody, dermal-epidermal junction, cytokine

\section{INTRODUCTION}

Bullous pemphigoid (BP), by far the most common autoimmune blistering disease, is induced by autoantibodies against the structural components of the dermal-epidermal junction (DEJ) (1). In most cases, the disease develops cryptically (2). The suggested causes of BP include silicosis (3), psoralen and ultraviolet A therapy (4), infections (5), physical or chemical insults (6-8), certain fruits (9), and medications $(10,11)$. However, the validation of these factors in the pathogenesis of BP remains be established. BP mainly affects the older age group of both sexes, or those 70 years old and above, but it can also affect infants, children, and adolescents $(1,12)$. This disease mainly involves the skin but occasionally the eyes, mouth, and genitals $(1,2)$. The cutaneous manifestations of BP are polymorphic and can be classified into three groups, namely classical BP, non-bullous cutaneous pemphigoid, and various rare variants $(13,14)$. Classical $\mathrm{BP}$ is clinically characterized by large $(1-3 \mathrm{~cm})$, tense, serous, or hemorrhagic blisters that appear on erythematous, urticarial, or eczematous lesions and even on apparently normal skin $(1,13)$. The biopsied lesions exhibit subepidermal splitting or blisters, which is the hallmark of $\mathrm{BP}$, with dense inflammatory infiltration of eosinophils, basophils, neutrophils, lymphocytes, and mast cells in the dermis (1). Immunofluorescence analysis is necessary for the diagnosis of BP (15). Direct immunofluorescence is the most sensitive method for BP diagnosis, in which the lesion shows linear deposition of immunoglobulin G (IgG), C3 complement, and even IgE at the DEJ (16-18). Indirect immunofluorescence using the patient's sera and a substrate, especially salt-split skin, reveals a linear deposition of IgG along the roof of the artificial split (18).

One typical serologic characteristic of $\mathrm{BP}$ is the presence of circulating autoantibodies, which are mostly against BP180 (collagen XVII) and BP230 $(15,19,20)$. BP180 is a $180 \mathrm{kDa}$ transmembrane 
glycoprotein with a 16th non-collagenous (NC16A) domain, which is the immunodominant part in BP (14). BP230 is an intracellular constituent of the hemidesmosomal plaque and belongs to the spectraplakin family $(20,21)$. The autoantibodies reported in BP include $\operatorname{IgG}$ and $\operatorname{IgE}(1,22)$. Usually, $\operatorname{IgG}$ autoantibodies to BP180 are the ones first to be detected, and then IgG autoantibodies to BP230 subsequently appear (23). IgE antibodies to BP230 can also be detected in the blood of BP patients (24). Given the existence of autoantibodies, there have been commercially available enzyme-linked immunosorbent assay (ELISA) kits that target BP180 and BP230 antibodies for BP auxiliary diagnosis $(25,26)$.

Due to the age group involved and the application of more sensitive and specific diagnostic assay systems, the reported BP morbidity has increased $(14,19,27,28)$. Moreover, for disease-specific factors, due to the concomitant occurrence of neurodegenerative disorders, use of higher doses of oral corticosteroids, and the propensity to malignancies and venous thromboembolism, BP mortality showed an increasing trend as well $(19,29-36)$. These findings suggested the contributory role of activation of blood coagulation in the pathogenesis of BP $(35,36)$. Presently, topical or systematic corticosteroids, with or without immunosuppressive agents, are still the mainstays for BP treatment $(1,14,37,38)$. Intravenous Ig has also been introduced as an alternative therapy for BP (39-41), however, its effectiveness is still questionable $(42,43)$. Therefore, it is of highly importance to discover new targets to reduce BP morbidity and mortality. Recently, increasing evidences show that autoimmune responses to BP180 are important in the initiation and evolution of BP (44). The binding of autoantibodies to BP180 is a central step for blister formation. Moreover, BP180 is associated with severe and extensive lesions that require higher dose of steroids, which is a key risk factor for death $(14,28,45)$. The serum level of anti-BP180 NC16A autoantibody correlates with the more active and severe disease, as well as poorer prognosis $(33,46)$. We, thus, consider BP180 as the most important culprit in the pathogenesis of BP and focused this review on recently updated knowledge on BP180 and its autoantibodies in BP.

\section{THE BASIC STRUCTURE OF BP180}

$\mathrm{BP} 180$ is a type II transmembrane protein with a cytosolic NH2 terminal and an extracellular $\mathrm{COOH}$ domain (47). The N-terminal domain, transmembranous stretch, and extracellular C-terminus have 466, 23, and 1,008 amino acids (aa) in length, respectively (48). The ectodomain contains 15 collagenous subdomains (COL1-COL15) interspersed by 16 non-collagenous sequences (NC1-NC16). The NC16A domain, a juxtamembranous linker region, appears to be biologically important, as it serves as the nucleus for the formation of a collagen-like triple helix $(49,50)$. The extracellular domain contains coiled-coil structures, which are physiologically shed from the cell surface by a disintegrin metalloproteinase (ADAM) (50). The ectodomain forms a loop structure as it spans the lamina lucida, extends to lamina densa, and then kinks back into the lamina lucida (49). BP180 contains multiple binding sites for hemidesmosome proteins, including the extracellular domains of integrin $\alpha 6$ and laminin-332 (laminin-5) and the cytoplasmic domains of integrin $\beta 4$, plectin, and BP230 (20). The structure and location of BP180 indicate that it acts as a core anchor protein that connects the intracellular and extracellular hemidesmosomal proteins and plays a key role in the pathogenesis of BP.

\section{THE EPITOPE PROFILES OF BP180}

Previous studies mainly focused on extracellular NC16A domain (aa residues 490-562), which is the main target of BP autoantibodies. The NC16A domain has seven antigenic sites, including NC16A1, NC16A1-3, NC16A1-5, NC16A2, NC16A2.5, NC16A3, and NC16A3-4 (51-53) (Figure 1). Among these sites, NC16A2 and NC16A2.5 are the major antigenic sites, which can be targeted by all IgG and IgE antibodies. However, recent studies have described additional autoantibody-binding domains of BP180, such as the intracellular domain (ICD) and ectodomain $(44,54)$. The ICD (aa 1-452) has five target sites, namely ICD A, ICD B, ICD C, ICD D, and ICD A-D, and a central region (aa 112-199) (Figure 1). A previously published study reported that out of 18 sera of BP patients, 16 reacted with recombinant ICDs and that most of the antibodies bind to the central portion (55). A great number of sera combined with at least one of the ICD regions. With regard to ectodomain, it has been reported that $7.8-47 \%$ of $\mathrm{BP}$ sera recognized the $\mathrm{C}$-terminal regions of the ectodomain (54, 56). Further mapping identified the six regions outside of NC16A that were recognized by the sera of the patients: aa 809-1106, aa $1080-1107$, aa $1280-1315$, aa $1331-1404$, aa $1365-1413$, and aa $1048-1465(11,52,54,57)$. aa $809-1106$ and aa $1080-1107$ were at the midportion, whereas aa 1331-1404 and aa 1365-1413 were at the COOH-terminal (Figure 1). Other epitopes embracing more than one domain, such as aa 467-567, aa 490-812, and aa $490-1497$, were also reported $(11,52)$. It has been suggested that the pattern of epitope recognition may influence the course of the disease (23). Therefore, the recognition of target regions within BP180 is substantial in understanding the disease initiation and clinical characteristics of BP.

\section{THE SOURCE OF AUTOANTIBODIES TO BP180}

The etiology of BP is complex, but the presence of autoantibodies was widely accepted as the sine qua non of the condition. Anti-BP180 autoantibodies also exist in healthy people, even though these antibodies are conformationally different from pathogenic ones; however, only those bound to skin basement membrane can induce $\mathrm{BP}$ - suggesting that autoantibodies in the healthy may not be pathological per se $(58,59)$. The autoantibodies may assume function of surveillance and self-tolerance (60). In pathologic conditions, self-tolerance of the autoantibodies is dysfunctional, thus leading to the production of a higher-level of autoantibodies that bind to skin basement membrane and give rise to the occurrence of $\mathrm{BP}$. The development of $\mathrm{BP}$ suggests that there is a threshold or checkpoint in terms of autoantibody generation (61). It remains unclear why immune tolerance to BP180 is dysfunctional in some individuals. Previous study 


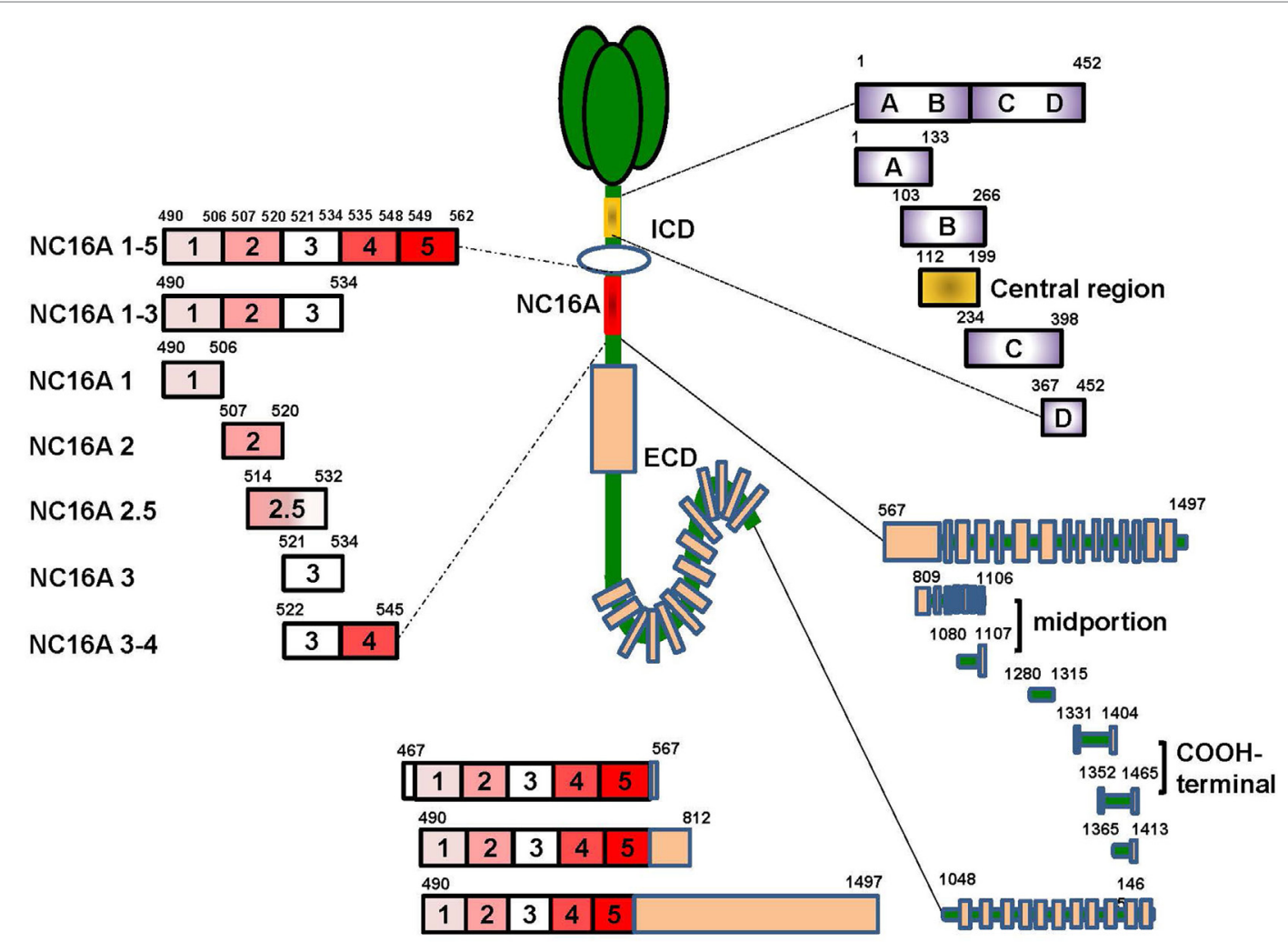

FIGURE 1 | The target sites of the BP180 molecule. BP180 is a multi-epitope protein with three major domains-the intracellular domain (ICD), the NC16A domain and the ectodomain outside NC16A domain. The ICD include five target sites, including aa 1-452, aa 1-133, aa 103-266, aa 234-398, aa 36-452 and a central region aa 112-199. The NC6A domain contain seven targeted sites, that is, NC16A1-5, 1-3, 1, 2, 2.5, 3, 3-4. The ectodomain domain also have eight functional sites, namely aa 567-1497, aa 809-1106, aa 1080-1107, aa 1280-1315, aa 1331-1404, aa 1352-1465, aa 1365-1413, and aa 1048-1465. Additionally, there are also target sites crossing more than one domain, such as aa 46-567, aa 490-812, and aa 490-1497.

suggests that CD4+ CD25+ Foxp3+ regulatory T (Treg) cells play an indispensable role in maintaining self-tolerance and in suppressing excessive production of autoantibodies deleterious to the host (62-65).

The reduction of CD4+ CD25+ Foxp3+ Treg cells in BP, as induced by triggers that are variants of pre-existing genetic factors, such as HLA-BQB1*0301, CYP2D6, MT-ATP8, and so on, leads to the breakage of self-tolerance, followed by the increase in autoreactive Th2, Th1, and B cells that can recognize different domains of BP180 mediated by epitope spreading to produce different autoantibodies (14, 44, 59, 65-69). The pathogens can exacerbate the process by sensitizing B cells via binding to toll-like receptors. The autoreactive $\mathrm{T}$ cells can interact with autoreactive B cells via combinations of CD40L-CD40, B-cell activating factor-transmembrane activator and CAML interactor (TACI)/B-cell maturation antigen, and proliferation-inducing ligand-TACI to further break peripheral tolerance and induce Ig production and class switching (70-74) (Figure 2). Moreover, the reactivity of T and $\mathrm{B}$ cells that target the $\mathrm{NH} 2$-terminal portion of the BP180 ectodomain is associated with severe BP, whereas the crosstalk of T and B cells targeting the central portion of BP180 is more frequently recognized in limited BP (75). The exploration in gene therapy might provide clues to retrieve Treg-mediated tolerance and to hinder the production of autoantibodies in skingrafted animals (76).

\section{AUTOANTIBODIES TARGETING NC16A OF BP180}

Previously, most studies pointed out that the NC16A might be the major pathogenic epitope in $\mathrm{BP}(47,74)$. ELISA analysis using

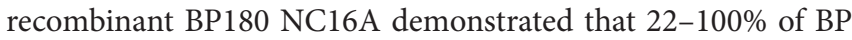
sera reacted to $\mathrm{BP} 180 \mathrm{NC} 16 \mathrm{~A}$ peptides and that autoantibodies targeting NC16A domain are associated with tense blisters, severe urticarial erythema, extensive lesions, and elevated eosinophils $(45,77)$. Therefore, there is a variety of autoantibody types that act on this domain and mediate various pathogenesis.

\section{Anti-NC16A IgG}

Anti-NC16A IgG is associated with BP-affected areas and with the occurrence of erosions and blisters in BP (46). High titers of anti-BP180 NC16A IgG at the time of therapy cessation represented the main factor in the prediction of risk of relapse in $\mathrm{BP}$ (78). Passive transfer of rabbit antimurine IgG antibodies against BP180 can lead to the development of BP-like skin phenotype, in 


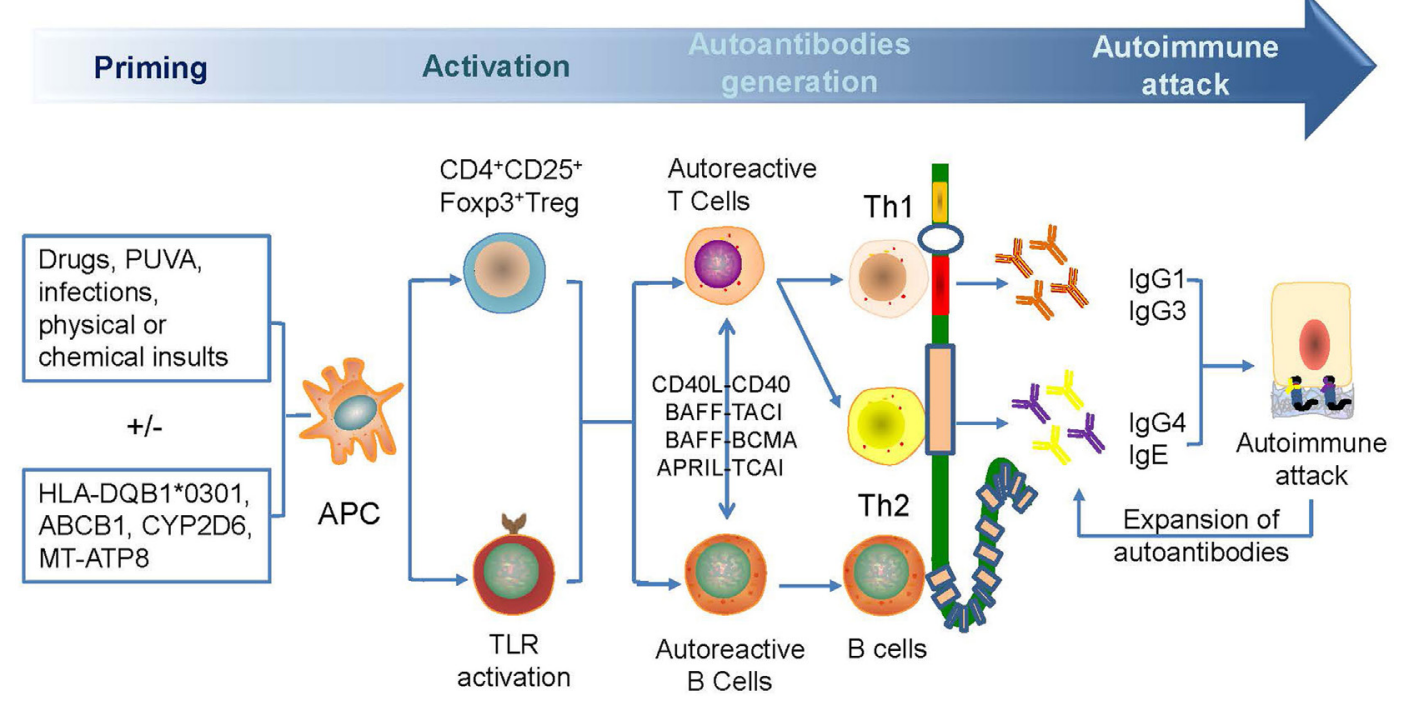

FIGURE 2 | A possible mechanism for the generation of anti-BP180 autoantibodies. Antibodies are generated for the breakage of self-tolerance which is caused by drugs, psoralen, and ultraviolet A therapy, infections, physical, or chemical insults. Autoactivated Th1 and Th2 and B cell can target different domains of BP180, leading to the generation of anti-BP180 autoantibodies via epitope spreading and lg class-switch. Such autoantibodies could be present in the serum for a long time before occurrence of clinical features. Attacked BP180 can be a source of new antigens to initiate the further expansion of autoantibodies and acceleration of disease.

which the mechanisms involved are complement activation, mast cell degradation, neutrophil infiltration, production of reactive oxygen species and proteases, and BP180 degradation (14, 79); and these mechanisms suggest a complement-dependent inflammatory pathway in BP development. The pathways induced by antimurine BP180 NC16A domain is further verified in studies using mast cell-deficient (80), C5-null (16), C4-null, alternative pathway component factor B-deficient $(28,81)$, membrane CD46 upregulated (82), Fab-IgG-deficient (83), and Fc $\gamma$ R-deficient (84) mice. All these studies were able to identify the complementdependent inflammatory pathway of anti-BP180 NC16A IgG (Figure 3A).

There are complement-independent mechanisms that account for the induction of BP by anti-NC16A IgG. Nearly one-fifth of BP cases may develop blisters in a complement-independent manner mainly through BP internalization (16) Immunofluorescence microscopy revealed that BP180 content in BP lesions is reduced by approximately $40 \%$ (85). As demonstrated by vibration assay in vitro, keratinocytes stimulated with anti-NC16A IgG demonstrated BP180 internalization and significant decrease in cell-plate adhesion (86). Further supporting data stem from an in vivo study using neonatal C3-deficient BP180-humanized mice without complement activation (87). The effects are attributed to the internalization of BP180/anti-BP180 complex via a macropinocytic pathway, which involves ICD phosphorylation by protein kinase $\mathrm{C}$ and potential degradation of BP180 through a ubiquitin/proteasome pathway $(85,88,89)$. As BP-IgG-induced BP180 internalization is insufficient to induce blister formation, various inflammatory responses mediated by Fc $\gamma \mathrm{R}$-independent and $\mathrm{F} c \gamma \mathrm{R}$-dependent pathways must be involved, which further lead to a BP-specific split (85). At least interleukin (IL)-6 and IL-8, which are induced by autoantibodies, participate in the inflammatory responses $(28,90)$ In addition, neutrophils partly recruited by IL- 8 are also essential for blister formation (91) (Figure 3B). These studies emphasized the complement-independent inflammatory pathway of anti-BP180 NC16A IgG.

However, the role of complements in BP pathogenesis, as mediated by anti-BP180 NC16A IgG autoantibodies, is still controversial. Negative C3 deposition along the epidermal basement membrane zone was found in $16.9 \%$ of BP lesions (16). Antihuman BP180 NC16A IgG4, which has low ability to bind to the Fc receptor and fixing complement, can induce dermalepidermal separation in in vitro cryosection assays and blister formation in patients $(89,92)$. IgG4 autoantibodies are also the major IgG subclasses of autoantibodies found in more than $54.4 \%$ of BP patients, and it is parallel with the disease severity (93). An in vitro study found that anti-NC16A IgG4 might prevent the induction of BP blistering by competitively inhibiting the binding of IgG1 and IgG3 autoantibodies to the NC16A region and by blocking IgG1 - and IgG3-induced complement fixation and neutrophil infiltration (94). Another study reported that anti-NC16A IgG4 has a protective role in $\mathrm{BP}$ (94). However, the provided C5a complement could successfully induce BP through anti-NC16A IgG4 (94). The revealed discrepancies may be explained by the different research methods used in the studies, as well as the complexity of BP, or by the possibility that the protective role of IgG4 autoantibodies in BP is due to the competitive blockade of IgG1 and IgG3 autoantibodies, which in turn gives rise to the suppression of complement-dependent blister formation. However, the "IgG4-dominant complement-independent BP" cannot be excluded. When the abovementioned studies are summarized, as well as the findings of complement fixation at basement 


\section{A}

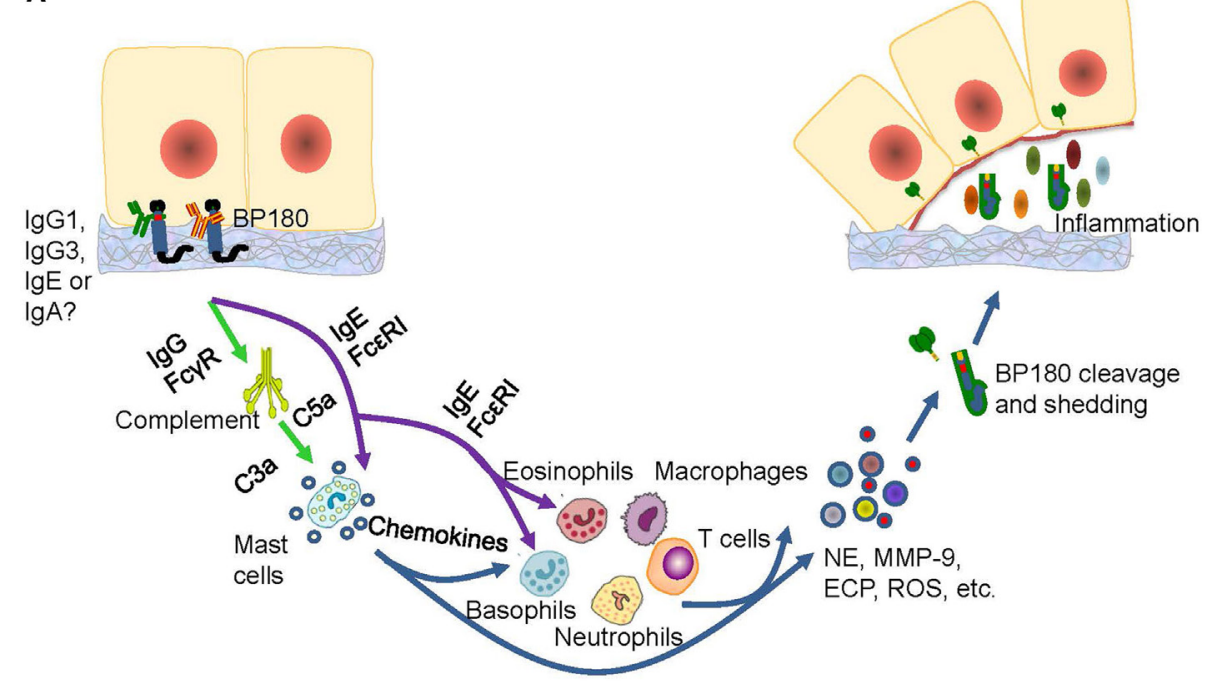

B

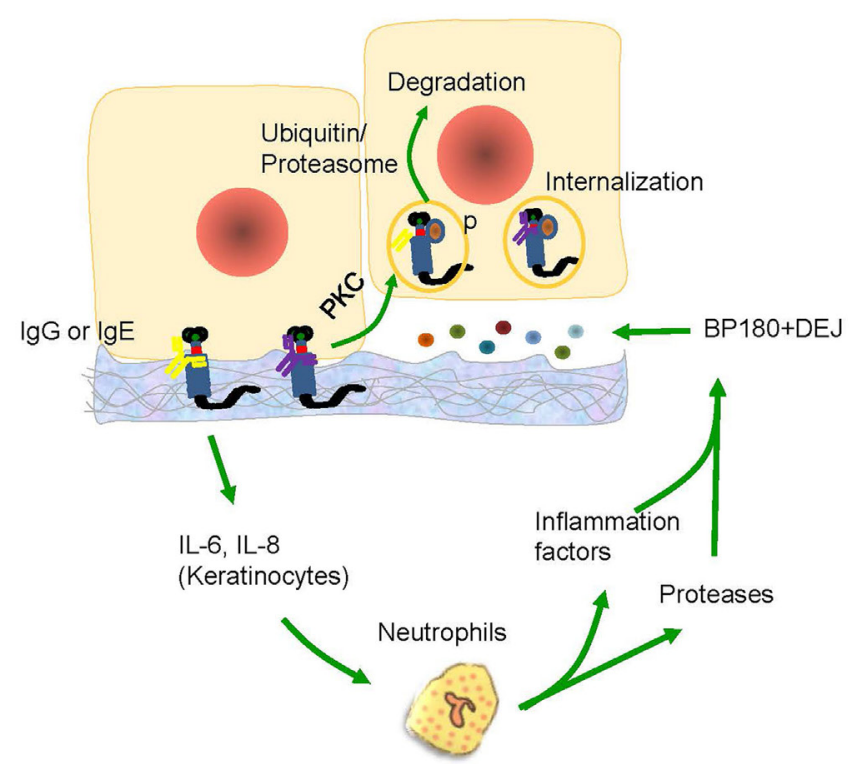

FIGURE 3 | The possible pathogenic mechanism of the anti-BP180 NC16A autoantibodies. (A) The IgG1, IgG3, IgE, or IgA anti-BP180 NC16A autoantibodiesmediated pathways for blister formation in bullous pemphigoid (BP). The binding of IgG1, IgG3 with NC16A activates complements via FcyR followed by mast cell degradation and neutrophilic, eosinophilic, basophilic, and macrophage infiltration, which lead to the degradation of BP180 by releasing inflammatory factors and proteases. While the IgE anti-BP180 NC16A autoantibodies activate infiltration of mast cell, eosinophils, and basophils via FceRI. (B) The immunoglobulin G (IgG) or IgE-mediated pathways for blister formation in BP. On the one hand, the binding of IgG or IgE with NC16A domain activates the protein kinase C followed by BP180 phosphorylation and degradation, which leads to the reduced adhesion. The binding, on the other hand, causes the release of interleukin (IL)-6 and IL-8 by keratinocytes, which prompts recruitment of neutrophils, release of inflammatory factors and neutrophil elastase (NE), and blister formation.

membrane in BP patients, we can conclude that complement amplifies blister formation by inducing inflammation $(16,51,95)$.

\section{Anti-NC16A IgE}

In addition to the IgG autoantibodies, $22-100 \%$ BP patients also produce IgE autoantibodies against BP180 NC16A (24, 46, $96,97)$. The level of anti-NC16A IgE is correlated with disease activity $(24,46)$, occurrence of urticarial lesions and erythema (46, 98, 99), higher prednisolone dosage, longer duration before remission, and more intensive therapies
(100). Immunofluorescence revealed the deposition of IgE autoantibodies along the DEJ in up to $41 \%$ of BP patients (101). Moreover, the early pathological changes in BP, including urticaria, eosinophil infiltration, and spontaneous blistering, can only be observed in models that utilized $\operatorname{IgE}$ autoantibodies from patient sera or recombinant monoclonal $\operatorname{IgE}$ antibodies specific for BP180 (102). These observations indicate that IgE autoantibodies may also be involved in the pathogenesis of BP and correlate with certain distinct clinical features. Furthermore, epitope mapping studies have demonstrated that 
these IgE autoantibodies preferably target the NC16A domain of the BP180 protein as IgG $(46,53,103)$.

Injecting purified anti-BP180 NC16A IgE autoantibodies into human skin grafted on nu/nu mice can induce histologic dermal-epidermal separation, as well as erythematous and urticarial plaques; and the mechanisms of these processes include mast cell infiltration and degranulation and influx of eosinophils, lymphocytes, and neutrophils (104). An in vitro investigation showed that the injection of IgE into the dermis of a human cryosection model led to histologic separation at the DEJ through the binding of FceRI on mast cell surface, which triggered mast cell degranulation, subsequent eosinophil infiltration, and direct activation of eosinophils and basophils mediated by high-affinity FceRI (95, $105,106)$. Interestingly, the amount of circulating eosinophils is correlated with the levels of both NC16A-specific IgG and IgE in BP sera (106). These results provide indirect evidence that anti-BP180 NC16A IgE autoantibodies contribute to BP-like damage and to certain distinct clinical features by triggering mast cell degranulation and basophil histamine release that is FceRI dependent $(106,107)$ (Figure 3A). The successful use of omalizumab in preventing the interaction of IgE with FceRI in BP patients further verifies the FceRI-dependent pathways (108, 109). However, recent studies also revealed that IgE autoantibodies from BP patients could be internalized into cultured human keratinocytes or skin tissues where they stimulate production of IL- 6 and IL- 8 and lead to the depletion of hemidesmosomes, as observed through BP IgG autoantibodies and as the effect of antiNC16A IgG on keratinocytes in vitro (110-112) (Figure 3B). These studies suggest that the direct function of anti-BP180 NC16A IgE autoantibodies is to promote inflammation and fragility of the DEJ in BP. Further studies utilizing IgE monoclonal antibody are necessary to explore the mechanisms underlying NC16A-specific IgE autoantibody-mediated tissue damage in BP (113).

\section{Anti-NC16A IgA}

An increasing number of studies reported the potential role of anti-BP180 IgA, aside from anti-NC16A IgG and IgE, in BP pathogenesis $(52,107,114,115)$. Comparable to $\operatorname{IgG}$ and $\operatorname{IgE}$, IgA autoantibodies mainly target the NC16A domain (106). Anti-BP180 NC16A IgA can be found in sera of $20-65 \%$ of BP patients $(51,113)$; and it can also be detected in the saliva of $36 \%$, parotid gland of $44 \%$, and in sera of $28 \%$ of mucous membrane pemphigoid patients (114). Moreover, IgA basement membrane zone deposition has been reported in $13 \%$ of BP patients $(17,116)$. However, investigation that mechanistically elucidates the functions of IgA autoantibodies in BP are still lacking. Epitope spreading or antibody class switching are likely to be involved in the pathogenesis of BP, as there is a determined clinical association between BP and linear IgA bullous disease (LAD) $(114,117)$. Recent studies reported that there is a linear IgA deposition in basement membrane zone, which is dapsone-responsive and characterized by a flexural distribution of intensely pruritic subepidermal bullae, thus suggesting that IgA might be associated with specific clinical features of BP or that BP may have comparable or overlapping pathomechanisms with LAD $(118,119)$. Like LAD, the anti-BP180 IgA autoantibodies directly act on NC16A domain, leading to the release of inflammatory factors and neutrophils, degranulation of neutrophils and mast cells, and release of proteolytic enzymes-all of which are similar to the effects of IgG and IgE (118) (Figure 3A). In fact, most serum samples from LAD and BP patients contain both IgA and IgG antibodies against BP180 (114, 120, 121). Thus, the two diseases could be regarded as different ends of a continuous spectrum of autoimmune responses to BP180 in subepidermal blistering diseases (119). Further studies using cell and animal models are needed to comprehensively unveil the pathogenic role of anti-BP180 NC16A IgA autoantibodies.

\section{AUTOANTIBODIES TARGETING ICD AND ECTODOMAIN OF BP180}

Recent studies reported that $59-82 \%$ of BP sera can recognize the ICD of BP180, while $7.8-49 \%$ of $\mathrm{BP}$ sera are reactive against the ectodomain of BP180 (54, 77, 122, 123). All autoantibodies, including IgG, IgE, and IgA, can target ICD; however, these autoantibodies bind to different sites $(55,114,122,123)$. The autoantibodies can penetrate live cells, reach their intracellular targets, and alter cellular functions (124) (Figure 4). The central region of BP180 ICD harbors binding sites that are critical for the interaction of BP180 with $\beta 4$ subunit of the $\alpha 6 \beta 4$ integrin, which is vital for the incorporation of the protein into the hemidesmosome (49). Thus, it implicates that autoantibodies against BP180 ICD impair the interaction of BP180 with other molecular constituents of the hemidesmosome. Otherwise, the damaged basal keratinocyte induced by the binding of autoantibodies to BP180 ectodomain leads to the exposure of the ICD to the immune system, which is referred to as "epitope spreading" (125) (Figure 4).

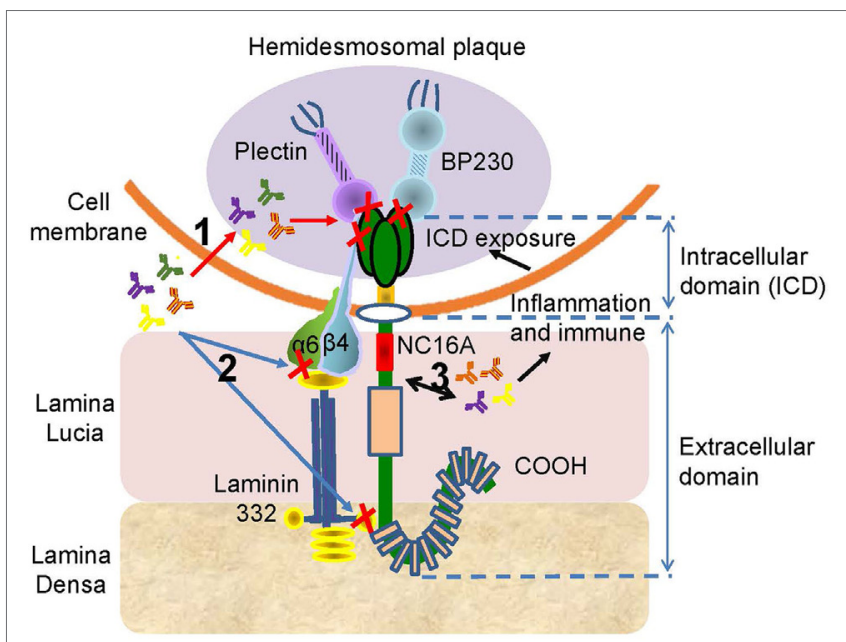

FIGURE 4 | The potential pathogenesis of the anti-BP180 autoantibodies targeting the intracellular domain (ICD) or the ectodomain outside the NC16A. There are three possible mechanism associated the autoantibodies with ICD or ectodomain. (1) The autoantibodies penetrate cells, reach the ICD, and inhibit the interaction of BP180 with plectin, BP230, or $\beta 4$. (2) The binding of autoantibodies with ectodomain interferes the interplay of BP180, $\alpha 6, \beta 4$, and laminin-332. (3) The interaction between autoantibodies and ectodomain induces inflammatory and immune responses, which lead to the exposure of the ICD, initiating the effect of autoantibodies on ICD. 
In addition, the $\mathrm{COOH}$-terminal region of the BP180 ectodomain is shown to be recognized by $47 \%$ of $\mathrm{BP}$ sera (56). IgG, $\mathrm{IgE}$, and IgA autoantibodies can all bind to the terminal region $(52,54,103,122)$. The presence of autoantibodies against $\mathrm{N}$ - or C-terminal portions of the BP180 ectodomain is associated with the mucosal lesions in BP patients $(56,126)$. In addition, there are existing autoantibodies against the midportion of BP180; and these are associated with the occurrence of hemiplegia, clinical presentation of lack of erythema around the bullae, and histopathologic eosinophil infiltration inside and around subepidermal bullae (57). Other studies revealed that high levels of autoantibodies against $\mathrm{C}$-terminal portions are associated with older age, administration of dipeptidyl peptidase- 4 inhibitors before BP onset, and a positive response to moderate doses of oral prednisolone $(11,123)$. However, there is also a report refuting the association of autoantibodies with dipeptidyl peptidase- 4 inhibitors (127). As BP180 extends from the cytoplasm of the basal keratinocyte to the lamina densa, it is presumed that the autoantibodies against this region might be responsible for the scarring phenotype observed in cicatricial pemphigoid patients (56) (Figure 4). The development of novel ELISA kits to detect the autoantibodies against the ectodomain, or even ICD, is beneficial in diagnosing BP without NC16A domain $(56,128)$.

More novel animal models have been recently constructed, thus making it possible to determine the role of different domains. One of the animal models is the $\triangle \mathrm{NC} 14 \mathrm{~A}$ mice, which have BP180 NC14A replaced with the homologous human BP180 NC16A epitope cluster region (129). BP lesion develops in these $\triangle \mathrm{NC} 14 \mathrm{~A}$ mice after passive transfer of BP IgG (129). The NC14A region can also be genetically deleted in C57BL/6 mice, which then have less amount of BP180 in skin but have normal ectodomain shedding (130). They spontaneously produce IgG and IgA autoantibodies against BP180 and present eosinophilic infiltrations, as well as the clinical features of pruritus and crusted erosions (130). Hence, the $\triangle \mathrm{NC} 14 \mathrm{~A}$ mice may be an ideal experimental model for investigating the early clinical changes in BP. However, in the absence of NC16A domain, it is impossible to explore the detailed functions of anti-NC16A autoantibodies. It is also presumed that the pruritus and eosinophils are associated with the ectodomain. Therefore, the $\triangle \mathrm{NC} 14 \mathrm{~A}$ mice may be utilized as a model for the exploration of autoantibodies acting on the ICD or on the ectodomain. However, the mechanisms involved remain to be confirmed. Another animal model is the COL17-humanized mice, which can express human BP180, and it is suitable for the analysis of the pathogenesis of BP in humans (131). The spontaneous production of high titers of anti-BP180 antibodies in blisters and erosions on erythematous skin lesions makes the observation of dynamic immune reactions possible. The pathogenicity of autoantibodies against ICD and ectodomain of BP180 remains unclear, and further studies are warranted. The development of novel ELISA system to detect such autoantibodies is necessary (77).

\section{IgM AUTOANTIBODIES IN BP}

An IgM-mediated BP has been recently reported $(132,133)$. Direct immunofluorescence microscopy showed that linear deposition of IgM can be found at the DEJ of 6-22\% of BP patients $(17,134,135)$. However, the target of $\operatorname{IgM}$ autoantibodies is unknown, and immunoblotting with recombinant protein of BP180 C-terminal domain showed multiple non-specific bands (136). IgM is mainly associated with BP caused by lupus erythematosus (132); however, it is rarely associated with BP due to infections (137), macroglobulinemia $(136,138)$, and surgical factors (139). The presence of IgM autoantibodies seems to not influence the course or outcome of the disease; and the role of IgM autoantibodies in the pathophysiology of BP remains elusive.

\section{THE CLEAVAGE AND DEPLETION OF BP180}

Followed by various autoantibody-mediated inflammatory responses, the BP180 cleavage and depletion have been proposed as the terminal effect that causes reduced adhesion and blister formation. In vitro, the cleavage and shedding of BP180 ectodomain is an event related to detachment, migration, proliferation, differentiation, and wound healing of keratinocytes (50, 140-144). Generally, the cleaved ectodomain does not generate pathogenic epitopes. However, excessive cleavage, shedding, or depletion can lead to reduced adhesion and blister formation.

Bullous pemphigoid autoantibody-induced infiltration of mast cells, eosinophils, and neutrophils can lead to the production of various inflammatory factors and proteases that contribute to the induction of blister formation. Increased levels of IL-1 $\beta$, IL-2, IL-4, IL-5, IL-6, IL-8, IL-10, IL-13, IL-17, IL-22, IL-23, IL-31, IL-36, interferon- $\gamma$, tumor necrosis factor (TNF)- $\alpha$, transforming growth factor- $\beta$, RANTES (regulated on activation, normal $\mathrm{T}$ cell expressed and secreted), monocyte chemotactic protein 1 , interferon gamma-induced protein 10 , and $\mathrm{C}-\mathrm{C}$ chemokine ligand (CCL) 17 have been detected in skin lesions, serum, or blister fluid of BP patients $(14,19,97,145-150)$. In addition, C-C chemokine receptor 3 ligands, such as CCL 11, CCL13, CCL18, CCL26, and CCL28, have been shown to be increased in skin and/or sera of BP patients $(43,146,151,152)$. Increased levels of CCL1, CCL2, and chemokine C-X-C motif ligand-10 were detected in sera of BP patients $(153,154)$. Moreover, increasing data revealed their functional involvements in BP $(97,149,151$, 153, 155-158) (Figure 5A). The proteases produced by inflammatory cells are functionally involved as well $(79,159)$ (Figure 5B). The inflammatory cells can release mast cell protease (MCP)-4, matrix metalloproteinase (MMP)-9, neutrophil elastase (NE), plasmin, and eosinophil cationic protein (ECP), which cleave and degrade BP180, thus leading to dermal-epidermal separation and blister formation (20, 149, 157, 160-164) Pathogenic anti-BP180 IgG failed to induce subepidermal blistering in mice that were deficient in either NE or MMP-9 (89). MMP-9 can regulate NE activity by inactivating $\alpha 1$-proteinase inhibitor ( $\alpha 1-\mathrm{PI})$ (159). Furthermore, $\alpha 1-\mathrm{PI}$ serves as a chemoattractant for neutrophils once it is cleaved and exacerbates tissue damage (165). MMP-9 can also cleave BP180 into small tripeptides ProGly-Pro, which significantly enhance neutrophil chemotaxis and NE release (149). These infiltrated cells also release IL-17, which significantly upregulates the production of MMP-9 and elastase in 


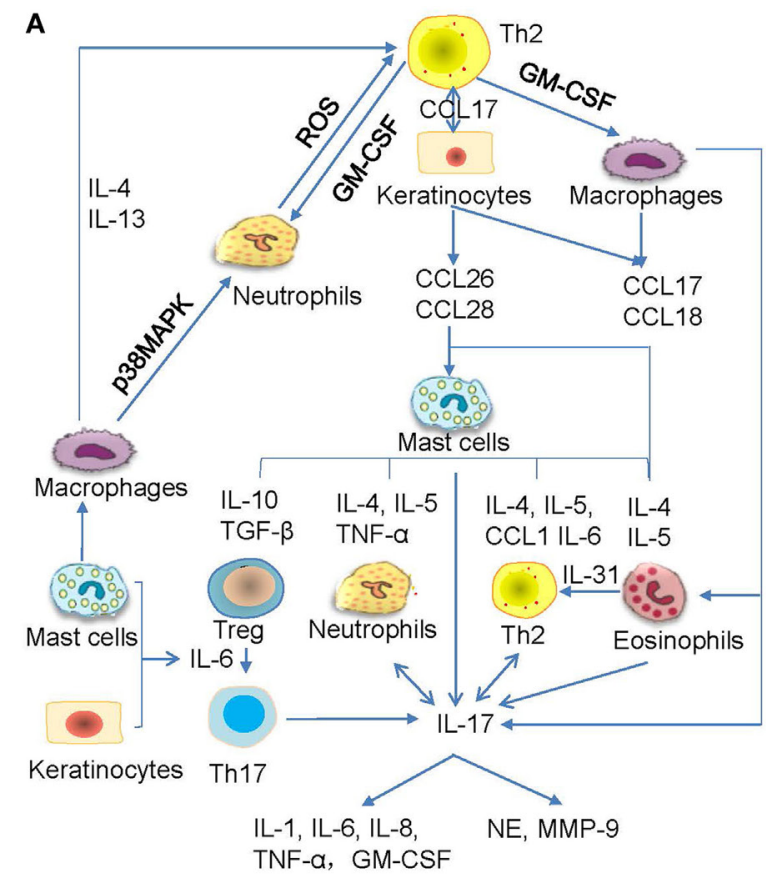

B

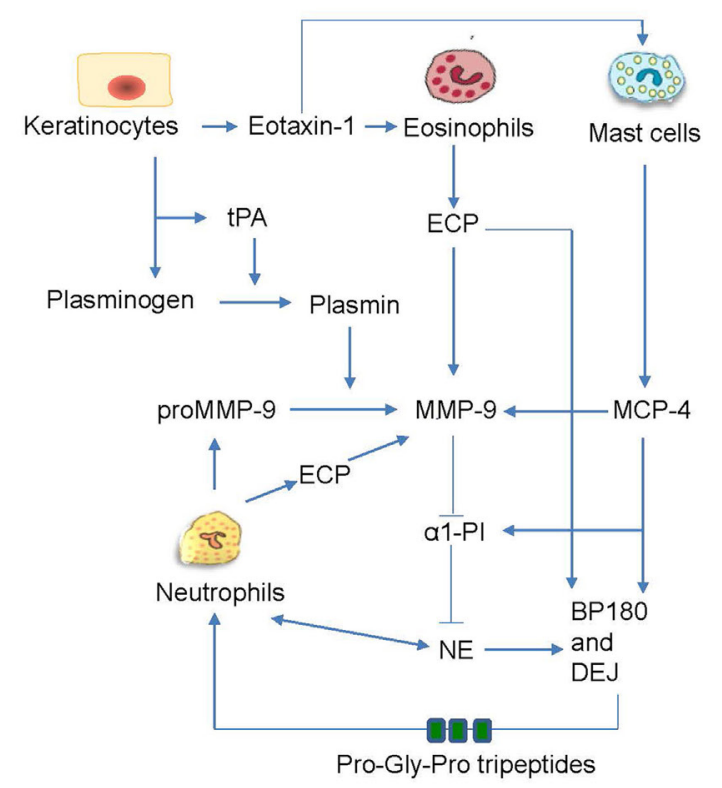

FIGURE 5 | The crosstalk networks of the inflammatory cells and the proteases. (A) The autoactive Th2 cells secrete type II cytokines, which act on macrophages, keratinocytes, and fibroblasts and induce the chemotaxis of mast cells. The mast cells produce various cytokines and chemokines, which act on the regulatory T (Treg) cells, neutrophils, Th2, eosinophils, and macrophages. All these inflammatory cells can release interleukin (IL)-17, which not only act on neutrophils and Th2 but also prompt inflammatory response and proteases release. (B) The keratinocytes synthesize tissue plasmogen activator (tPA), which activates plasmin followed by the activation of matrix metalloproteinase (MMP)-9. The eosinophil cationic protein (ECP) and mast cell protease (MCP)-4 can also activate MMP-9. MMP-9 inhibits production of $\alpha 1$-proteinase inhibitor $(\alpha 1$-PI) while promote generation of neutrophil elastase (NE). All these proteases act on BP180 and dermalepidermal junction (DEJ). The cleaved BP180 can release pro-gly-pro tripeptides and attract neutrophils. neutrophils $(149,166)$. The released IL-17 could, in turn, stimulate neutrophils to produce more IL-17 and form an amplified loop (167) (Figure 5A). Therefore, inflammatory factors and proteases induced by inflammatory cells play key roles in the cleavage and depletion of BP180, and targeting these inflammatory networks may be a promising therapeutic strategy in the treatment of BP.

However, BP180 cleavage may also occur in the absence of anti-BP180 autoantibodies (140). Such physiological cleavage is mediated by ADAMs (140). Our study further reveals that TNFlike weak inducer of apoptosis (TWEAK), which is a multifaceted cytokine that participates in various skin inflammatory responses, can exacerbate the BP180 reduction and keratinocyte adhesion (19). Moreover, the effect of TWEAK on BP180 cleavage involves the activation of extracellular signal-regulated kinase and nuclear factor- $\kappa \mathrm{B}$ pathways as well as the downstream ADAMs, in which ADAM 8, 9, 10, 15, and 17 have been suggested to participate in BP180 cleavage or BP development $(19,168,169)$. We also found high expression of MMP-9, ADAM9, ADAM10, and ADAM17 in BP lesions and in keratinocytes upon TWEAK/Fn14 activation (19). The upregulation of MMP-9 and ADAM10 is responsible for the shedding of membrane CD46, which further enhances BP180 NC16A IgG-mediated complement activation and blister formation (82). Therefore, the role of TWEAK in BP development can be mainly ascribed to the abnormally high expression of ADAMs and other proteases. By considering the absence or insignificant expression of TWEAK in noninvolved skin, we conclude that TWEAK likely plays a secondary inflammatory role rather than being a primary participant $(19,170)$. Further investigations are required to establish the clear-cut function of TWEAK in BP.

\section{POTENTIAL THERAPEUTIC TARGETS}

Considerable progress made by recent studies updated our understanding of BP pathogenesis. The availability of novel BP animal models provides important tools to further gain insights on the pathophysiology of the autoimmune disease. However, there is a limited progress regarding BP therapy. As BP180 is a molecule with multiple epitopes, a better insight on the mechanisms of immune responses induced by binding of autoantibodies to BP180 on different epitopes is crucial for the design of novel and more specific therapeutic strategies for this life-threatening autoimmune disorder (Table 1).

\section{The Recovery of Immune Tolerance}

Targeting immune tolerance is a coveted approach for the treatment of various autoimmune diseases, as current treatment options often involve non-specific immunosuppression. BP is closely associated with the disturbance of self-tolerance, in which the reduction in Treg cells plays a key role. Therefore, the increase in Treg cells will help to recover immune tolerance and prevent BP development. Previously, recombinant IL-10 has been used to increase circulating Treg cells and to lower CD4+ T cells (171). The use of low-dose recombinant IL-2 could also induce significant expansion of Treg cells in vivo and preferentially restore Treg cells (172). Low-dose IL-2-induced Treg cell proliferation is subsequently followed by increased programmed cell death 1 (PD-1) expression (173). PD-1 inhibitor causes BP eruptions, thus 
TABLE 1 | Potential treatment targets for bullous pemphigoid (BP).

\begin{tabular}{|c|c|c|c|c|}
\hline Categories & Targets & Drugs or methods & Potential effects & Reference \\
\hline \multirow{5}{*}{$\begin{array}{l}\text { Immune } \\
\text { tolerance }\end{array}$} & \multirow{3}{*}{$\begin{array}{l}\text { Regulatory } T \\
\text { (Treg) cells }\end{array}$} & Interleukin (IL)-10 & Increasing Treg cells & $(171)$ \\
\hline & & Low-dose IL-2 & Inducing significant Treg cells expansion & $(172,173)$ \\
\hline & & Oxymatrine & $\begin{array}{l}\text { Upregulating FOXP3 Treg cells and reducing the production of tumor necrosis factor- } \alpha \\
\text { and IL-17A }\end{array}$ & $(174)$ \\
\hline & BP180 NC16A & $\begin{array}{l}\text { Gene gun delivery of NC16a- } \\
\text { encoding DNA }\end{array}$ & Inducting tolerance of BP180 & $(175)$ \\
\hline & BP180 & $\begin{array}{l}\text { Lactic-co-glycolic acid } \\
\text { nanoparticles }\end{array}$ & Inducing antigen-specific T cell tolerance & $(176)$ \\
\hline \multirow[t]{3}{*}{ B cells } & \multirow[t]{3}{*}{ CD20 } & Rituximab & Reducing all subclasses of immunoglobulin G (lgG) anti-BP180 autoantibodies & $(102,177)$ \\
\hline & & $\begin{array}{l}\text { Rituximab and intravenous } \\
\text { immunoglobulin }\end{array}$ & $\begin{array}{l}\text { Producing a prolonged and sustained remission in patients with active and recalcitrant } \\
\text { BP }\end{array}$ & $(39,178)$ \\
\hline & & Calcineurin inhibitors & Suppressing naive B cells & $(179)$ \\
\hline \multirow[t]{3}{*}{ T cells } & CD25 & Anti-CD25 antibodies & Targeting IL-2 receptor on activated T cells & $(180)$ \\
\hline & Calcineurin & Calcineurin inhibitors & $\begin{array}{l}\text { Inhibiting nuclear factor of activated T cells and blocking T-cell-dependent production } \\
\text { of lgG }\end{array}$ & $(181)$ \\
\hline & CD4+ T cells & $\mathrm{IL}-10$ & Lowering the number of circulating CD4+ T cells & $(171)$ \\
\hline \multirow[t]{3}{*}{ Co-stimulators } & \multirow[t]{2}{*}{ BAFF-APRIL } & Tabaluma (anti-BAFF) & Neutralizing autoreactive and memory B cells & $(182)$ \\
\hline & & Anti-APRIL & Anti-proliferation and reducing autoantibodies production & $(183,184)$ \\
\hline & CD40-CD40L & Anti-CD40 & $\begin{array}{l}\text { Regulating both innate and adaptive immunity and the activation of antigen-specific } \\
T \text { cells }\end{array}$ & $(185)$ \\
\hline \multirow[t]{3}{*}{ Autoantibodies } & $\lg G$ & SM101 & A soluble Fc $\gamma R$ that competes with the interaction of lgG with membrane Fc $\gamma$ Rs & $(186)$ \\
\hline & $\lg E$ & Omalizumab & Inhibiting IgE binding to FceRl & $(108)$ \\
\hline & Autoantibodies & Immunoadsorption & Declining the serum autoantibody levels & $(187,188)$ \\
\hline
\end{tabular}

$A P R I L$, a proliferation-inducing ligand; BAFF, B-cell activating factor.

suggesting the value of targeting PD-1 upregulation in BP treatment $(102,189)$. Oxymatrine, a monosomic alkaloid extracted from the Chinese herb Sophora flavescens Ait, can upregulate FOXP3+ Treg cells and reduce the production of TNF- $\alpha$ and IL-17A, thus aiding in the recovery of immune tolerance (174). Previously, nanotechnology is therapeutically used to inhibit the detrimental immune responses in autoimmunity through its direct immunosuppressive effect on antigen-presenting cells B and $\mathrm{T}$ cells, or indirectly by delivering compounds that result in immunotolerance (190). Gene gun delivery of NC16A-encoding DNA on gold particles results in Treg cell-mediated tolerance to BP180 (175). Antigen-coupled biodegradable poly (lactic-coglycolic acid) nanoparticles have been used to induce antigenspecific $\mathrm{T}$ cell tolerance, which is a promising method that targets organ-specific BP (176). All aforementioned methods could improve immune tolerance and block the potential production of autoantibodies.

\section{Therapeutic Prevention of Excessive Antibody Production}

Targeting the effector $\mathrm{B}$ and $\mathrm{T}$ cells to prevent the production of "pathogenic" autoantibodies may be a promising method in BP treatment. Rituximab used for depleting CD20+ B cells can reduce all subclasses of anti-BP180 IgG antibodies and has shown efficacy in case reports of patients with refractory BP $(39,177,178)$. Autoreactive T cells are also associated with IgG autoantibodies production. Targeting autoreactive $\mathrm{T}$ cells using
anti-CD25 antibodies and calcineurin inhibitors could modulate immune responses $(181,191)$. Anti-CD25 antibodies bind to high-affinity heterotrimeric IL-2 receptor on activated $\mathrm{T}$ cells, block the IL-2/IL-2 receptor signaling, and inhibit the propagation of $\mathrm{T}$ cell activation, thereby limiting the damaging effects of further $\mathrm{T}$ cell recruitment in autoimmune diseases (180). Calcineurin can dephosphorylate and inhibit nuclear factors of activated $\mathrm{T}$ cells and regulate $\mathrm{T}$-cell activation and differentiation (181). The inhibition of nuclear factors of activated T cells may directly suppress skin injuries by blocking T-cell-dependent production of IgG, as IgG deposition is central to the development of bullae in BP. Additionally, the interaction between T and B cells needs co-stimulatory factors. Hence, targeting co-stimulatory molecules using special monoclonal antibodies could also disrupt the interaction of $\mathrm{T}$ and $\mathrm{B}$ cells and block the synthesis of autoantibodies $(182-185,192)$. For pathogen-induced BP, the suppression of dendritic cell-mediated autoimmunity or toll-like receptor antagonist is also practicable $(193,194)$.

\section{Neutralization of Pathogenic Antibodies}

Immunoglobulin $\mathrm{G}$ autoantibodies are the main pathogenetic antibodies that act on $\mathrm{Fc} \gamma \mathrm{R}$ to induce blister production. SM101, a soluble Fc $\gamma$ R, competes with the interaction of IgG and membrane Fc $\gamma$ Rs and prevents the development of BP (186). Omalizumab, which targets IgE autoantibodies, can neutralize the activity of IgE in BP and control the disease activity (108). Furthermore, therapies targeting IgE-mast cells-eosinophils/ 
basophils interaction may also demonstrate promising results in the treatment of BP (112). Moreover, immunoadsorption with high-affinity matrices that selectively bind to human IgG and IgE provides an alternative way of removing autoantibodies $(187,195)$.

\section{Prospective}

Despite the complexity and diversity of the dermatosis, there is still hope for BP patients. Novel promising agents targeting different mechanisms of BP development are necessary. In addition, a multifactorial animal model for BP is warranted as well, and it should mimic not only the presence of specific pathogenic autoantibodies but also the additional triggers, such as environmental factors, medications, comorbid conditions, and infections, in disease initiation. Furthermore, future investigations are required as there may be the presence of unidentified antigenic epitopes that are indispensable for disease development.

\section{CONCLUSION}

Bullous pemphigoid has been regarded as a well-characterized, organ-specific, mainly anti-BP180 autoantibody-mediated blistering skin disorder. Both IgG and IgE play vital roles in

\section{REFERENCES}

1. Schmidt E, Zillikens D. Pemphigoid diseases. Lancet (2013) 381:320-32. doi:10.1016/s0140-6736(12)61140-4

2. Rosenbach M, Wanat KA, Lynm C. Bullous pemphigoid. JAMA Dermatol (2013) 149:382. doi:10.1001/jamadermatol.2013.112

3. Zhu T, Ma DL, Zeng YP, Song L, Li L. Bullous pemphigoid associated with silicosis. J Eur Acad Dermatol Venereol (2017). doi:10.1111/jdv.14419

4. Caca-Biljanovska N, Arsovska-Bezhoska I, V’Lckova-Laskoska M. PUVAinduced bullous pemphigoid in psoriasis. Acta Dermatovenerologica Croatica (2016) 24:214-7.

5. Sagi L, Baum S, Agmon-Levin N, Sherer Y, Katz BS, Barzilai O, et al. Autoimmune bullous diseases the spectrum of infectious agent antibodies and review of the literature. Autoimmun Rev (2011) 10:527-35. doi:10.1016/j. autrev.2011.04.003

6. Wang HE, Wells JM, Rizk DV. Bullous lesions after use of a commercial therapeutic hypothermia temperature management system: a possible burn injury? Ther Hypothermia Temp Manag (2013) 3:147-50. doi:10.1089/ ther.2013.0013

7. Shon W, Wada DA, Kalaaji AN. Radiation-induced pemphigus or pemphigoid disease in 3 patients with distinct underlying malignancies. Cutis (2016) 97:219-22.

8. Annabestani Z, Mohseni S, Torkaman G, Nasirpoor F, Larijani B, MohajeriTehrani MR. Electrical stimulation-induced bullous formation in a pemphigoid diabetic patient: a case report. Int J Diabetes Dev Ctries (2015) 35:55-7. doi:10.1007/s13410-014-0212-0

9. Belcher MD, Kaddour-Djebbar I, Bollag WB, Davis LS. The proteolytic effect of bromelain on bullous pemphigoid antigen-2. J Am Acad Dermatol (2016) 75:838-40. doi:10.1016/j.jaad.2016.05.025

10. Kanahara SM, Agrawal A. Drug-induced bullous pemphigoid. J Gen Intern Med (2016) 31:1393-4. doi:10.1007/s11606-016-3679-1

11. Sakai A, Shimomura Y, Ansai O, Saito Y, Tomii K, Tsuchida Y, et al. Linagliptin-associated bullous pemphigoid that was most likely caused by IgG autoantibodies against the midportion of BP180. Br J Dermatol (2017) 176:541-3. doi:10.1111/bjd.15111

12. Zhao CY, Murrell DF. Blistering diseases in neonates. Curr Opin Pediatr (2016) 28:500-6. doi:10.1097/mop.0000000000000381

13. Cozzani E, Gasparini G, Burlando M, Drago F, Parodi A. Atypical presentations of bullous pemphigoid: clinical and immunopathological
BP development via complement-dependent or -independent inflammatory pathways. However, the roles of IgA and IgM are still uncertain, and further investigation is needed. Knowledge of the BP180 target sites and of the interaction between BP 180 and anti-BP180 autoantibodies is pivotal for the exploration of novel and more specific therapeutic methods so as to reduce BP morbidity and mortality. The translation of bench findings into bedside strategies for the treatment of this complex disease still remains to be a challenge. Although BP180-based therapy appears not to be close at hand yet, a better understanding of the role of BP180 would further approximate that to practice.

\section{AUTHOR CONTRIBUTIONS}

YL and YX conceived this paper. YL and LL wrote this manuscript. All the authors read and approved the final manuscript.

\section{FUNDING}

This study was supported by the National Natural Science Foundation of China (Projects No.81472876 and No.81630081) and the Natural Science Foundation of Shaanxi Province (No.2017ZDJC-06).

aspects. Autoimmun Rev (2015) 14:438-45. doi:10.1016/j.autrev.2015 01.006

14. Bagci IS, Horvath ON, Ruzicka T, Sardy M. Bullous pemphigoid. Autoimmun Rev (2017) 16:445-55. doi:10.1016/j.autrev.2017.03.010

15. Bernard P, Antonicelli F. Bullous pemphigoid: a review of its diagnosis, associations and treatment. Am J Clin Dermatol (2017) 18:513-28. doi:10.1007/s40257017-0264-2

16. Romeijn TR, Jonkman MF, Knoppers C, Pas HH, Diercks GF. Complement in bullous pemphigoid: results from a large observational study. $\mathrm{Br} J$ Dermatol (2017) 176:517-9. doi:10.1111/bjd.14822

17. Moriuchi R, Nishie W, Ujiie H, Natsuga K, Shimizu H. In vivo analysis of IgE autoantibodies in bullous pemphigoid: a study of 100 cases. J Dermatol Sci (2015) 78:21-5. doi:10.1016/j.jdermsci.2015.01.013

18. Sardy M, Kostaki D, Varga R, Peris K, Ruzicka T. Comparative study of direct and indirect immunofluorescence and of bullous pemphigoid 180 and 230 enzyme-linked immunosorbent assays for diagnosis of bullous pemphigoid. J Am Acad Dermatol (2013) 69:748-53. doi:10.1016/j.jaad.2013.07.009

19. Liu Y, Peng L, Li L, Liu C, Hu X, Xiao S, et al. TWEAK/Fn14 activation contributes to the pathogenesis of bullous pemphigoid. J Invest Dermatol (2017) 137(7):1512-22. doi:10.1016/j.jid.2017.03.019

20. Furue M, Kadono T. Bullous pemphigoid: what's ahead? J Dermatol (2016) 43:237-40. doi:10.1111/1346-8138.13207

21. Ali A, Hu L, Zhao F, Qiu W, Wang P, Ma X, et al. BPAG1, a distinctive role in skin and neurological diseases. Semin Cell Dev Biol (2017) 69:34-9. doi:10.1016/j.semcdb.2017.06.005

22. Osawa M, Ueda-Hayakawa I, Isei T, Yoshimura K, Fukuda S, Hashimoto T, et al. A case of childhood bullous pemphigoid with IgG and IgA autoantibodies to various domains of BP180. J Am Acad Dermatol (2014) 70:e129-31. doi:10.1016/j.jaad.2013.06.006

23. Di Zenzo G, Thoma-Uszynski S, Calabresi V, Fontao L, Hofmann SC, Lacour JP et al. Demonstration of epitope-spreading phenomena in bullous pemphigoid: results of a prospective multicenter study. J Invest Dermatol (2011) 131:2271-80. doi:10.1038/jid.2011.180

24. Hashimoto T, Ohzono A, Teye K, Numata S, Hiroyasu S, Tsuruta D, et al. Detection of IgE autoantibodies to BP180 and BP230 and their relationship to clinical features in bullous pemphigoid. Br J Dermatol (2011) 177:141-51. doi:10.1111/bjd.15114

25. Keller JJ, Kittridge AL, Debanne SM, Korman NJ. Evaluation of ELISA testing for BP180 and BP230 as a diagnostic modality for bullous pemphigoid: 
a clinical experience. Arch Dermatol Res (2016) 308:269-72. doi:10.1007/ s00403-016-1631-1

26. van Beek N, Dahnrich C, Johannsen N, Lemcke S, Goletz S, Hubner F, et al. Prospective studies on the routine use of a novel multivariant enzyme-linked immunosorbent assay for the diagnosis of autoimmune bullous diseases. J Am Acad Dermatol (2017) 76:889-94.e5. doi:10.1016/j.jaad.2016.11.002

27. Tampoia M, Giavarina D, Di Giorgio C, Bizzaro N. Diagnostic accuracy of enzyme-linked immunosorbent assays (ELISA) to detect anti-skin autoantibodies in autoimmune blistering skin diseases: a systematic review and meta-analysis. Autoimmun Rev (2012) 12:121-6. doi:10.1016/j. autrev.2012.07.006

28. Nishie W. Update on the pathogenesis of bullous pemphigoid: an autoantibody-mediated blistering disease targeting collagen XVII. J Dermatol Sci (2014) 73:179-86. doi:10.1016/j.jdermsci.2013.12.001

29. Barrick BJ, Lohse CM, Lehman JS. Specific causes of death in patients with bullous pemphigoid as measured by death certificate data: a retrospective cohort study. Int J Dermatol (2015) 54:56-61. doi:10.1111/ijd.12243

30. Atzmony L, Mimouni I, Reiter O, Leshem YA, Taha O, Gdalevich M, et al. Association of bullous pemphigoid with malignancy: a systematic review and meta-analysis. J Am Acad Dermatol (2017) 77:691-9. doi:10.1016/j. jaad.2017.05.006

31. Lai YC, Yew YW, Lambert WC. Bullous pemphigoid and its association with neurological diseases: a systematic review and meta-analysis. J Eur Acad Dermatol Venereol (2016) 30:2007-15. doi:10.1111/jdv.13660

32. Cugno M, Marzano AV, Bucciarelli P, Balice Y, Cianchini G, Quaglino P, et al. Increased risk of venous thromboembolism in patients with bullous pemphigoid. The INVENTEP (INcidence of VENous ThromboEmbolism in bullous Pemphigoid) study. J Thromb Haemost (2016) 115:193-9. doi:10.1160/th15-04-0309

33. Liu YD, Wang YH, Ye YC, Zhao WL, Li L. Prognostic factors for mortality in patients with bullous pemphigoid: a meta-analysis. Arch Dermatol Res (2017) 309:335-47. doi:10.1007/s00403-017-1736-1

34. Li J, Zuo YG, Zheng HY. Mortality of bullous pemphigoid in China. JAMA Dermatol (2013) 149:106-8. doi:10.1001/archdermatol.2012.2994

35. Marzano AV, Tedeschi A, Berti E, Fanoni D, Crosti C, Cugno M. Activation of coagulation in bullous pemphigoid and other eosinophil-related inflammatory skin diseases. Clin Exp Immunol (2011) 165:44-50. doi:10.1111/j.1365-2249. 2011.04391.x

36. Marzano AV, Tedeschi A, Fanoni D, Bonanni E, Venegoni L, Berti E, et al. Activation of blood coagulation in bullous pemphigoid: role of eosinophils, and local and systemic implications. Br J Dermatol (2009) 160:266-72. doi:10.1111/j.1365-2133.2008.08880.x

37. Grantham HJ, Stocken DD, Reynolds NJ. Doxycycline: a first-line treatment for bullous pemphigoid? Lancet (2017) 389:1586-8. doi:10.1016/s01406736(17)30549-4

38. Williams HC, Wojnarowska F, Kirtschig G, Mason J, Godec TR, Schmidt E, et al. Doxycycline versus prednisolone as an initial treatment strategy for bullous pemphigoid: a pragmatic, non-inferiority, randomised controlled trial. Lancet (2017) 389:1630-8. doi:10.1016/s0140-6736(17)30560-3

39. Ahmed AR, Shetty S, Kaveri S, Spigelman ZS. Treatment of recalcitrant bullous pemphigoid (BP) with a novel protocol: a retrospective study with a 6-year follow-up. J Am Acad Dermatol (2016) 74:700-8.e3. doi:10.1016/j. jaad.2015.11.030

40. Tuchinda P, Ritchie S, Gaspari AA. Bullous pemphigoid treated with intravenous immunoglobulin. Cutis (2014) 93:264-8.

41. Amagai M, Ikeda S, Hashimoto T, Mizuashi M, Fujisawa A, Ihn H, et al. A randomized double-blind trial of intravenous immunoglobulin for bullous pemphigoid. J Dermatol Sci (2017) 85:77-84. doi:10.1016/j.jdermsci. 2016.11.003

42. von Gunten S, Shoenfeld Y, Blank M, Branch DR, Vassilev T, Kasermann F, et al. IVIG pluripotency and the concept of Fc-sialylation: challenges to the scientist. Nat Rev Immunol (2014) 14:349. doi:10.1038/nri3401-c1

43. Ruocco E, Wolf R, Caccavale S, Brancaccio G, Ruocco V, Lo Schiavo A. Bullous pemphigoid: associations and management guidelines: facts and controversies. Clin Dermatol (2013) 31:400-12. doi:10.1016/j.clindermatol.2013. 01.007

44. Pickford WJ, Gudi V, Haggart AM, Lewis BJ, Herriot R, Barker RN, et al. $\mathrm{T}$ cell participation in autoreactivity to NC16a epitopes in bullous pemphigoid. Clin Exp Immunol (2015) 180:189-200. doi:10.1111/cei.12566
45. Kalowska M, Ciepiela O, Kowalewski C, Demkow U, Schwartz RA, Wozniak K. Enzyme-linked immunoassay index for anti-NC16a IgG and IgE auto-antibodies correlates with severity and activity of bullous pemphigoid. Acta Derm Venereol (2016) 96:191-6. doi:10.2340/00015555-2101

46. van Beek N, Luttmann N, Huebner F, Recke A, Karl I, Schulze FS, et al. Correlation of serum levels of IgE autoantibodies against BP180 with bullous pemphigoid disease activity. JAMA Dermatol (2017) 153:30-8. doi:10.1001/ jamadermatol.2016.3357

47. Wada M, Nishie W, Ujiie H, Izumi K, Iwata H, Natsuga K, et al. Epitopedependent pathogenicity of antibodies targeting a major bullous pemphigoid autoantigen collagen XVII/BP180. J Invest Dermatol (2016) 136:938-46. doi:10.1016/j.jid.2015.11.030

48. Wei W, He HL, Chen CY, Zhao Y, Jiang HL, Liu WT, et al. Whole exome sequencing implicates PTCH1 and COL17A1 genes in ossification of the posterior longitudinal ligament of the cervical spine in Chinese patients. Genet Mol Res (2014) 13:1794-804. doi:10.4238/2014.March.17.7

49. Walko G, Castanon MJ, Wiche G. Molecular architecture and function of the hemidesmosome. Cell Tissue Res (2015) 360:529-44. doi:10.1007/ s00441-015-2216-6

50. Nishie W, Jackow J, Hofmann SC, Franzke CW, Bruckner-Tuderman L. Coiled coils ensure the physiological ectodomain shedding of collagen XVII. J Biol Chem (2012) 287:29940-8. doi:10.1074/jbc.M112.345454

51. Natsuga K, Nishie W, Shinkuma S, Ujiie H, Nishimura M, Sawamura D, et al. Antibodies to pathogenic epitopes on type XVII collagen cause skin fragility in a complement-dependent and -independent manner. J Immunol (2012) 188:5792-9. doi:10.4049/jimmunol.1003402

52. Horvath B, Niedermeier A, Podstawa E, Muller R, Hunzelmann N, Karpati S, et al. IgA autoantibodies in the pemphigoids and linear IgA bullous dermatosis. Exp Dermatol (2010) 19:648-53. doi:10.1111/j.1600-0625.2010.01080.x

53. Dopp R, Schmidt E, Chimanovitch I, Leverkus M, Brocker EB, Zillikens D. IgG4 and IgE are the major immunoglobulins targeting the NC16A domain of BP180 in Bullous pemphigoid: serum levels of these immunoglobulins reflect disease activity. J Am Acad Dermatol (2000) 42:577-83. doi:10.1067/ mjd.2000.103986

54. Fairley JA, Bream M, Fullenkamp C, Syrbu S, Chen M, Messingham KN. Missing the target: characterization of bullous pemphigoid patients who are negative using the BP180 enzyme-linked immunosorbant assay. J Am Acad Dermatol (2013) 68:395-403. doi:10.1016/j.jaad.2012.09.012

55. Dresow SK, Sitaru C, Recke A, Oostingh GJ, Zillikens D, Gibbs BF. IgE autoantibodies against the intracellular domain of BP180. Br J Dermatol (2009) 160:429-32. doi:10.1111/j.1365-2133.2008.08858.x

56. Hofmann S, Thoma-Uszynski S, Hunziker T, Bernard P, Koebnick C, Stauber A, et al. Severity and phenotype of bullous pemphigoid relate to autoantibody profile against the $\mathrm{NH} 2$ - and $\mathrm{COOH}$-terminal regions of the BP180 ectodomain. J Invest Dermatol (2002) 119:1065-73. doi:10.1046/j.1523-1747. 2002.19529.x

57. Tsuruta D, Nishikawa T, Yamagami J, Hashimoto T. Unilateral bullous pemphigoid without erythema and eosinophil infiltration in a hemiplegic patient. J Dermatol (2012) 39:787-9. doi:10.1111/j.1346-8138.2012.01562.x

58. Wieland CN, Comfere NI, Gibson LE, Weaver AL, Krause PK, Murray JA. Anti-bullous pemphigoid 180 and 230 antibodies in a sample of unaffected subjects. Arch Dermatol (2010) 146:21-5. doi:10.1001/archdermatol.2009.331

59. Xu L, Robinson N, Miller SD, Chan LS. Characterization of BALB/c mice B lymphocyte autoimmune responses to skin basement membrane component type XVII collagen, the target antigen of autoimmune skin disease bullous pemphigoid. Immunol Lett (2001) 77:105-11. doi:10.1016/S0165-2478 (01)00212-7

60. Madi A, Bransburg-ZabaryS, Maayan-Metzger A, Dar G, Ben-JacobE, Cohen IR. Tumor-associated and disease-associated autoantibody repertoires in healthy colostrum and maternal and newborn cord sera. J Immunol (2015) 194:5272-81. doi:10.4049/jimmunol.1402771

61. Olsen NJ, Karp DR. Autoantibodies and SLE: the threshold for disease. Nat Rev Rheumatol (2014) 10:181-6. doi:10.1038/nrrheum.2013.184

62. Yang S, Fujikado N, Kolodin D, Benoist C, Mathis D. Immune tolerance. Regulatory T cells generated early in life play a distinct role in maintaining self-tolerance. Science (2015) 348:589-94. doi:10.1126/science.aaa7017

63. Kalekar LA, Schmiel SE, Nandiwada SL, Lam WY, Barsness LO, Zhang N, et al. CD4(+) T cell anergy prevents autoimmunity and generates regulatory T cell precursors. Nat Immunol (2016) 17:304-14. doi:10.1038/ni.3331 
64. Baruch K, Rosenzweig N, Kertser A, Deczkowska A, Sharif AM, Spinrad A, et al. Breaking immune tolerance by targeting Foxp3(+) regulatory T cells mitigates Alzheimer's disease pathology. Nat Commun (2015) 6:7967. doi:10.1038/ncomms8967

65. Antiga E, Quaglino P, Volpi W, Pierini I, Del Bianco E, Bianchi B, et al. Regulatory T cells in skin lesions and blood of patients with bullous pemphigoid. JEur Acad Dermatol Venereol (2014) 28:222-30. doi:10.1111/jdv. 12091

66. Rychlik-Sych M, Baranska M, Wojtczak A, Skretkowicz J, Zebrowska A, Waszczykowska E. The impact of the CYP2D6 gene polymorphism on the risk of pemphigoid. Int J Dermatol (2015) 54:1396-401. doi:10.1111/ ijd.12967

67. Zakka LR, Reche P, Ahmed AR. Role of MHC Class II genes in the pathogenesis of pemphigoid. Autoimmun Rev (2011) 11:40-7. doi:10.1016/j. autrev.2011.07.002

68. Quaglino P, Antiga E, Comessatti A, Caproni M, Nardo T, Ponti R, et al. Circulating CD4+ CD25brightFOXP3+ regulatory T-cells are significantly reduced in bullous pemphigoid patients. Arch Dermatol Res (2012) 304:639-45. doi:10.1007/s00403-012-1213-9

69. Lo Schiavo A, Ruocco E, Brancaccio G, Caccavale S, Ruocco V, Wolf R. Bullous pemphigoid: etiology, pathogenesis, and inducing factors: facts and controversies. Clin Dermatol (2013) 31:391-9. doi:10.1016/j.clindermatol. 2013.01.006

70. Qian H, Kusuhara M, Li X, Tsuruta D, Tsuchisaka A, Ishii N, et al. B-cell activating factor detected on both naive and memory B cells in bullous pemphigoid. Exp Dermatol (2014) 23:596-605. doi:10.1111/exd.12421

71. Watanabe R, Fujimoto M, Yazawa N, Nakashima H, Asashima N, Kuwano Y, et al. Increased serum levels of a proliferation-inducing ligand in patients with bullous pemphigoid. J Dermatol Sci (2007) 46:53-60. doi:10.1016/j. jdermsci.2006.12.008

72. Wong HK, Bechtel MA. Blistering insights into the pathogenesis of bullous pemphigoid. Clin Immunol (2012) 142:101-4. doi:10.1016/j.clim.2011.12.003

73. Vincent FB, Saulep-Easton D, Figgett WA, Fairfax KA, Mackay F. The BAFF/APRIL system: emerging functions beyond B cell biology and autoimmunity. Cytokine Growth Factor Rev (2013) 24:203-15. doi:10.1016/j. cytogfr.2013.04.003

74. Ujiie H, Shibaki A, Nishie W, Shinkuma S, Moriuchi R, Qiao H, et al. Noncollagenous 16A domain of type XVII collagen-reactive CD4+ T cells play a pivotal role in the development of active disease in experimental bullous pemphigoid model. Clin Immunol (2012) 142:167-75. doi:10.1016/j. clim.2011.10.002

75. Thoma-Uszynski S, Uter W, Schwietzke S, Schuler G, Borradori L, Hertl M. Autoreactive $\mathrm{T}$ and $\mathrm{B}$ cells from bullous pemphigoid (BP) patients recognize epitopes clustered in distinct regions of BP180 and BP230. J Immunol (2006) 176:2015-23. doi:10.4049/jimmunol.176.3.2015

76. Lin MS, Fu CL, Giudice GJ, Olague-Marchan M, Lazaro AM, Stastny P, et al. Epitopes targeted by bullous pemphigoid T lymphocytes and autoantibodies map to the same sites on the bullous pemphigoid 180 ectodomain. J Invest Dermatol (2000) 115:955-61. doi:10.1046/j.1523-1747.2000.00153.x

77. Izumi K, Nishie W, Mai Y, Wada M, Natsuga K, Ujiie H, et al. Autoantibody profile differentiates between inflammatory and noninflammatory bullous pemphigoid. J Invest Dermatol (2016) 136:2201-10. doi:10.1016/j. jid.2016.06.622

78. Fichel F, Barbe C, Joly P, Bedane C, Vabres P, Truchetet F, et al. Clinical and immunologic factors associated with bullous pemphigoid relapse during the first year of treatment: a multicenter, prospective study. JAMA Dermatol (2014) 150:25-33. doi:10.1001/jamadermatol.2013.5757

79. de Graauw E, Sitaru C, Horn M, Borradori L, Yousefi S, Simon HU, et al. Evidence for a role of eosinophils in blister formation in bullous pemphigoid. Allergy (2017) 72:1105-13. doi:10.1111/all.13131

80. Yu X, Kasprick A, Petersen F. Revisiting the role of mast cells in autoimmunity. Autoimmun Rev (2015) 14:751-9. doi:10.1016/j.autrev.2015. 04.008

81. Nelson KC, Zhao M, Schroeder PR, Li N, Wetsel RA, Diaz LA, et al. Role of different pathways of the complement cascade in experimental bullous pemphigoid. J Clin Invest (2006) 116:2892-900. doi:10.1172/jci17891

82. Qiao P, Dang E, Cao T, Fang H, Zhang J, Qiao H, et al. Dysregulation of mCD46 and sCD46 contribute to the pathogenesis of bullous pemphigoid. Sci Rep (2017) 7:145. doi:10.1038/s41598-017-00235-3
83. Wang G, Ujiie H, Shibaki A, Nishie W, Tateishi Y, Kikuchi K, et al. Blockade of autoantibody-initiated tissue damage by using recombinant fab antibody fragments against pathogenic autoantigen. Am J Pathol (2010) 176:914-25. doi:10.2353/ajpath.2010.090744

84. Schulze FS, Beckmann T, Nimmerjahn F, Ishiko A, Collin M, Kohl J, et al. Fcgamma receptors III and IV mediate tissue destruction in a novel adult mouse model of bullous pemphigoid. Am J Pathol (2014) 184:2185-96. doi:10.1016/j.ajpath.2014.05.007

85. Hiroyasu S, Ozawa T, Kobayashi H, Ishii M, Aoyama Y, Kitajima Y, et al. Bullous pemphigoid IgG induces BP180 internalization via a macropinocytic pathway. Am J Pathol (2013) 182:828-40. doi:10.1016/j.ajpath. 2012.11.029

86. Iwata H, Kitajima Y. Bullous pemphigoid: role of complement and mechanisms for blister formation within the lamina lucida. Exp Dermatol (2013) 22:381-5. doi:10.1111/exd.12146

87. Ujiie H, Sasaoka T, Izumi K, Nishie W, Shinkuma S, Natsuga K, et al. Bullous pemphigoid autoantibodies directly induce blister formation without complement activation. J Immunol (2014) 193:4415-28. doi:10.4049/jimmunol. 1400095

88. Iwata H, Kamaguchi $M$, Ujiie H, Nishimura M, Izumi $K$, Natsuga $K$, et al. Macropinocytosis of type XVII collagen induced by bullous pemphigoid IgG is regulated via protein kinase C. Lab Invest (2016) 96:1301-10. doi:10.1038/ labinvest.2016.108

89. Dainichi T, Chow Z, Kabashima K. IgG4, complement, and the mechanisms of blister formation in pemphigus and bullous pemphigoid. J Dermatol Sci (2017) 88:265-70. doi:10.1016/j.jdermsci.2017.07.012

90. Tukaj S, Gruner D, Tukaj C, Zillikens D, Kasperkiewicz M. Calcitriol exerts anti-inflammatory effects in keratinocytes treated with autoantibodies from a patient with bullous pemphigoid. J Eur Acad Dermatol Venereol (2016) 30:288-92. doi:10.1111/jdv.12929

91. VandenBerghF,EliasonSL, BurmeisterBT,GiudiceGJ. Collagen XVII(BP180) modulates keratinocyte expression of the proinflammatory chemokine, IL-8. Exp Dermatol (2012) 21:605-11. doi:10.1111/j.1600-0625.2012.01529.x

92. Dainichi T, Nishie W, Yamagami Y, Sonobe H, Ujiie H, Kaku Y, et al. Bullous pemphigoid suggestive of complement-independent blister formation with anti-BP180 IgG4 autoantibodies. Br J Dermatol (2016) 175:187-90. doi:10.1111/bjd.14411

93. Zhou XP, Liu B, Xu Q, Yang Y, He CX, Zuo YG, et al. Serum levels of immunoglobulins G1 and G4 targeting the non-collagenous 16A domain of BP180 reflect bullous pemphigoid activity and predict bad prognosis. J Dermatol (2016) 43:141-8. doi:10.1111/1346-8138.13051

94. Zuo Y, Evangelista F, Culton D, Guilabert A, Lin L, Li N, et al. IgG4 autoantibodies are inhibitory in the autoimmune disease bullous pemphigoid. J Autoimmun (2016) 73:111-9. doi:10.1016/j.jaut.2016.06.019

95. Hammers CM, Stanley JR. Mechanisms of disease: pemphigus and bullous pemphigoid. Annu Rev Pathol (2016) 11:175-97. doi:10.1146/ annurev-pathol-012615-044313

96. Bing L, Xiping Z, Li L, Jun P, Yi-Xia W, Min Y, et al. Levels of anti-BP180 NC16A IgE do not correlate with severity of disease in the early stages of bullous pemphigoid. Arch Dermatol Res (2015) 307:849-54. doi:10.1007/ s00403-015-1598-3

97. Salz M, Haeberle S, Hoffmann J, Enk AH, Hadaschik EN. Elevated IL-31 serum levels in bullous pemphigoid patients correlate with eosinophil numbers and are associated with BP180-IgE. J Dermatol Sci (2017) 87:309-11. doi:10.1016/j.jdermsci.2017.07.019

98. Cho YT, Liao SL, Wang LF, Chu CY. High serum anti-BP180 IgE levels correlate to prominent urticarial lesions in patients with bullous pemphigoid. J Dermatol Sci (2016) 83:78-80. doi:10.1016/j.jdermsci.2016.03.009

99. Kamiya K, Aoyama Y, Noda K, Miyake T, Yamaguchi M, Hamada T, et al. Possible correlation of IgE autoantibody to BP180 with disease activity in bullous pemphigoid. JDermatol Sci (2015) 78:77-9. doi:10.1016/j. jdermsci.2015.02.009

100. Iwata Y, Komura K, Kodera M, Usuda T, Yokoyama Y, Hara T, et al. Correlation of IgE autoantibody to BP180 with a severe form of bullous pemphigoid. Arch Dermatol (2008) 144:41-8. doi:10.1001/archdermatol.2007.9

101. Yayli S, Pelivani N, Beltraminelli H, Wirthmuller U, Beleznay Z, Horn M, et al. Detection of linear IgE deposits in bullous pemphigoid and mucous membrane pemphigoid: a useful clue for diagnosis. Br J Dermatol (2011) 165:1133-7. doi:10.1111/j.1365-2133.2011.10481.x 
102. Sowerby L, Dewan AK, Granter S, Gandhi L, LeBoeuf NR. Rituximab treatment of nivolumab-induced bullous pemphigoid. JAMA Dermatol (2017) 153:603-5. doi:10.1001/jamadermatol.2017.0091

103. Fairley JA, Fu CL, Giudice GJ. Mapping the binding sites of anti-BP180 immunoglobulin E autoantibodies in bullous pemphigoid. J Invest Dermatol (2005) 125:467-72. doi:10.1111/j.0022-202X.2005.23853.x

104. Fairley JA, Burnett CT, Fu CL, Larson DL, Fleming MG, Giudice GJ. A pathogenic role for IgE in autoimmunity: bullous pemphigoid IgE reproduces the early phase of lesion development in human skin grafted to nu/nu mice. J Invest Dermatol (2007) 127:2605-11. doi:10.1038/sj.jid.5700958

105. Messingham KN, Wang JW, Holahan HM, Srikantha R, Aust SC, Fairley JA. Eosinophil localization to the basement membrane zone is autoantibodyand complement-dependent in a human cryosection model of bullous pemphigoid. Exp Dermatol (2016) 25:50-5. doi:10.1111/exd.12883

106. Messingham KN, Holahan HM, Frydman AS, Fullenkamp C, Srikantha R, Fairley JA. Human eosinophils express the high affinity IgE receptor, FcepsilonRI, in bullous pemphigoid. PLoS One (2014) 9:e107725. doi:10.1371/journal. pone. 0107725

107. van Beek N, Schulze FS, Zillikens D, Schmidt E. IgE-mediated mechanisms in bullous pemphigoid and other autoimmune bullous diseases. Expert Rev Clin Immunol (2016) 12:267-77. doi:10.1586/1744666x.2016.1123092

108. Yu KK, Crew AB, Messingham KA, Fairley JA, Woodley DT. Omalizumab therapy for bullous pemphigoid. J Am Acad Dermatol (2014) 71:468-74. doi:10.1016/j.jaad.2014.04.053

109. Balakirski G, Alkhateeb A, Merk HF, Leverkus M, Megahed M. Successful treatment of bullous pemphigoid with omalizumab as corticosteroid-sparing agent: report of two cases and review of literature. J Eur Acad Dermatol Venereol (2016) 30:1778-82. doi:10.1111/jdv.13758

110. Messingham KN, Srikantha R, DeGueme AM, Fairley JA. FcR-independent effects of IgE and IgG autoantibodies in bullous pemphigoid. JImmunol (2011) 187:553-60. doi:10.4049/jimmunol.1001753

111. Iwata H, Kamio N, Aoyama Y, Yamamoto Y, Hirako Y, Owaribe K, et al. IgG from patients with bullous pemphigoid depletes cultured keratinocytes of the $180-\mathrm{kDa}$ bullous pemphigoid antigen (type XVII collagen) and weakens cell attachment. J Invest Dermatol (2009) 129:919-26. doi:10.1038/ jid.2008.305

112. Messingham KA, Holahan HM, Fairley JA. Unraveling the significance of IgE autoantibodies in organ-specific autoimmunity: lessons learned from bullous pemphigoid. Immunol Res (2014) 59:273-8. doi:10.1007/s12026-014-8547-7

113. Messingham KA, Onoh A, Vanderah EM, Giudice GJ, Fairley JA. Functional characterization of an IgE-class monoclonal antibody specific for the bullous pemphigoid autoantigen, BP180. Hybridoma (2005) 2012(31):111-7. doi:10.1089/hyb.2011.0102

114. Kromminga A, Scheckenbach C, Georgi M, Hagel C, Arndt R, Christophers E, et al. Patients with bullous pemphigoid and linear IgA disease show a dual IgA and IgG autoimmune response to BP180. J Autoimmun (2000) 15:293-300. doi:10.1006/jaut.2000.0437

115. Ali S, Kelly C, Challacombe SJ, Donaldson AN, Dart JK, Gleeson M, et al. Salivary IgA and IgG antibodies to bullous pemphigoid 180 noncollagenous domain 16 a as diagnostic biomarkers in mucous membrane pemphigoid. $\mathrm{Br}$ J Dermatol (2016) 174:1022-9. doi:10.1111/bjd.14351

116. Miyamoto S, Chikazu D, Yasuda T, Enomoto A, Oh-i T, Hirako Y, et al. A case of oral mucous membrane pemphigoid with IgG antibodies to integrin alpha6beta4. Br J Dermatol (2014) 171:1555-7. doi:10.1111/bjd.13113

117. Matsui K, Makino T, Takegami Y, Murayama S, Seki Y, Ishii N, et al. Bullous pemphigoid with IgG anti-LAD-1 antibodies. Eur JDermatol (2014) 24:275-6. doi:10.1684/ejd.2014.2322

118. Fortuna G, Marinkovich MP. Linear immunoglobulin A bullous dermatosis. Clin Dermatol (2012) 30:38-50. doi:10.1016/j.clindermatol.2011.03.008

119. Zillikens D, Herzele K, Georgi M, Schmidt E, Chimanovitch I, Schumann H, et al. Autoantibodies in a subgroup of patients with linear IgA disease react with the NC16A domain of BP1801. J Invest Dermatol (1999) 113:947-53. doi:10.1046/j.1523-1747.1999.00808.x

120. Christophoridis S, Budinger L, Borradori L, Hunziker T, Merk HF, Hertl M. IgG, IgA and IgE autoantibodies against the ectodomain of BP180 in patients with bullous and cicatricial pemphigoid and linear IgA bullous dermatosis. Br J Dermatol (2000) 143:349-55. doi:10.1046/j.1365-2133.2000.03661.x

121. Viglizzo G, Cozzani E, Nozza P, Occella C, Parodi A. A case of linear IgA disease in a child with IgA and IgG circulating antibodies directed to
BPAg2. Int J Dermatol (2007) 46:1302-4. doi:10.1111/j.1365-4632.2007. 03317.x

122. Perriard J, Jaunin F, Favre B, Budinger L, Hertl M, Saurat JH, et al. IgG autoantibodies from bullous pemphigoid (BP) patients bind antigenic sites on both the extracellular and the intracellular domains of the BP antigen 180. J Invest Dermatol (1999) 112:141-7. doi:10.1046/j.1523-1747.1999. 00497.x

123. Laffitte E, Skaria M, Jaunin F, Tamm K, Saurat JH, Favre B, et al. Autoantibodies to the extracellular and intracellular domain of bullous pemphigoid 180, the putative key autoantigen in bullous pemphigoid, belong predominantly to the IgG1 and IgG4 subclasses. Br J Dermatol (2001) 144:760-8. doi:10.1046/j. 1365-2133.2001.04130.x

124. Alarcon-Segovia D, Llorente L, Ruiz-Arguelles A. The penetration of autoantibodies into cells may induce tolerance to self by apoptosis of autoreactive lymphocytes and cause autoimmune disease by dysregulation and/or cell damage. J Autoimmun (1996) 9:295-300. doi:10.1006/jaut.1996.0038

125. Schmidt E, Skrobek C, Kromminga A, Hashimoto T, Messer G, Brocker EB, et al. Cicatricial pemphigoid: IgA and IgG autoantibodies target epitopes on both intra- and extracellular domains of bullous pemphigoid antigen $180 . \mathrm{Br}$ J Dermatol (2001) 145:778-83. doi:10.1046/j.1365-2133.2001.04471.x

126. Nakatani C, Muramatsu T, Shirai T. Immunoreactivity of bullous pemphigoid (BP) autoantibodies against the NC16A and C-terminal domains of the 180 $\mathrm{kDa}$ BP antigen (BP180): immunoblot analysis and enzyme-linked immunosorbent assay using BP180 recombinant proteins. Br J Dermatol (1998) 139:365-70. doi:10.1046/j.1365-2133.1998.02396.x

127. Tan CW, Pang Y, Sim B, Thirumoorthy T, Pang SM, Lee HY. The association between drugs and bullous pemphigoid. Br J Dermatol (2017) 176:549-51. doi:10.1111/bjd.15195

128. Mariotti F, Grosso F, Terracina M, Ruffelli M, Cordiali-Fei P, Sera F, et al. Development of a novel ELISA system for detection of anti-BP180 IgG and characterization of autoantibody profile in bullous pemphigoid patients. $\mathrm{Br}$ J Dermatol (2004) 151:1004-10. doi:10.1111/j.1365-2133.2004.06245.x

129. Liu Z, Sui W, Zhao M, Li Z, Li N, Thresher R, et al. Subepidermal blistering induced by human autoantibodies to BP180 requires innate immune players in a humanized bullous pemphigoid mouse model. J Autoimmun (2008) 31:331-8. doi:10.1016/j.jaut.2008.08.009

130. Hurskainen T, Kokkonen N, Sormunen R, Jackow J, Loffek S, Soininen R, et al. Deletion of the major bullous pemphigoid epitope region of collagen XVII induces blistering, autoimmunization, and itching in mice. J Invest Dermatol (2015) 135:1303-10. doi:10.1038/jid.2014.443

131. Ujiie H, Shibaki A, Nishie W, Sawamura D, Wang G, Tateishi Y, et al. A novel active mouse model for bullous pemphigoid targeting humanized pathogenic antigen. J Immunol (2010) 184:2166-74. doi:10.4049/jimmunol.0903101

132. Tazudeen N, Au S, Pewitt J, Tu E, Aronson IK. IgM ocular cicatricial pemphigoid: a unique insight into the immune system. Dermatol Online J (2015) 21.

133. Hashimoto T, Tsuruta D, Koga H, Fukuda S, Ohyama B, Komai A, et al. Summary of results of serological tests and diagnoses for 4774 cases of various autoimmune bullous diseases consulted to Kurume University. $\mathrm{Br}$ J Dermatol (2016) 175:953-65. doi:10.1111/bjd.14692

134. Glauser S, Rutz M, Cazzaniga S, Hegyi I, Borradori L, Beltraminelli H. Diagnostic value of immunohistochemistry on formalin-fixed, paraffin-embedded skin biopsy specimens for bullous pemphigoid. Br J Dermatol (2016) 175:988-93. doi:10.1111/bjd.14686

135. Arbache ST, Nogueira TG, Delgado L, Miyamoto D, Aoki V. Immunofluorescence testing in the diagnosis of autoimmune blistering diseases: overview of 10-year experience. An Bras Dermatol (2014) 89:885-9. doi:10.1590/ abd1806-4841.20143221

136. Maki N, Demitsu T, Umemoto N, Nagashima K, Nakamura T, Kakurai M, et al. Possible paraneoplastic syndrome case of bullous pemphigoid with immunoglobulin G anti-BP180 C-terminal domain antibodies associated with psoriasis and primary macroglobulinemia. J Dermatol (2016) 43:571-4. doi:10.1111/1346-8138.13170

137. Baroero L, Coppo P, Bertolino L, Maccario S, Savino F. Three case reports of post immunization and post viral bullous pemphigoid: looking for the right trigger. BMC Pediatr (2017) 17:60. doi:10.1186/s12887-017-0813-0

138. Chattopadhyay M, Rytina E, Dada M, Bhogal BS, Groves R, Handfield-Jones S. Immunobullous dermatosis associated with Waldenstrom macroglobulinaemia treated with rituximab. Clin Exp Dermatol (2013) 38:866-9. doi:10.1111/ ced. 12166 
139. Anderson CK, Mowad CM, Goff ME, Pelle MT. Bullous pemphigoid arising in surgical wounds. Br J Dermatol (2001) 145:670-2. doi:10.1046/j.13652133.2001.04427.x

140. Franzke CW, Tasanen K, Schacke H, Zhou Z, Tryggvason K, Mauch C, et al. Transmembrane collagen XVII, an epithelial adhesion protein, is shed from the cell surface by ADAMs. EMBO J (2002) 21:5026-35. doi:10.1093/emboj/ cdf532

141. Powell AM, Sakuma-Oyama Y, Oyama N, Black MM. Collagen XVII/ BP180: a collagenous transmembrane protein and component of the dermoepidermal anchoring complex. Clin Exp Dermatol (2005) 30:682-7. doi:10.1111/j.1365-2230.2005.01937.x

142. Jackow J, Loffek S, Nystrom A, Bruckner-Tuderman L, Franzke CW. Collagen XVII shedding suppresses re-epithelialization by directing keratinocyte migration and dampening mTOR signaling. J Invest Dermatol (2016) 136:1031-41. doi:10.1016/j.jid.2016.01.012

143. Jackow J, Schlosser A, Sormunen R, Nystrom A, Sitaru C, Tasanen K, et al. Generation of a functional non-shedding collagen XVII mouse model: relevance of collagen XVII shedding in wound healing. J Invest Dermatol (2016) 136:516-25. doi:10.1016/j.jid.2015.10.060

144. Nishie W, Natsuga K, Iwata H, Izumi K, Ujiie H, Toyonaga E, et al. Contextdependent regulation of collagen XVII ectodomain shedding in skin. Am J Pathol (2015) 185:1361-71. doi:10.1016/j.ajpath.2015.01.012

145. Kabuto M, Fujimoto N, Takahashi T, Tanaka T. Decreased level of interleukin-10-producing $B$ cells in patients with pemphigus but not in patients with pemphigoid. Br J Dermatol (2017) 176:1204-12. doi:10.1111/bjd.15113

146. Bieber K, Ernst AL, Tukaj S, Holtsche MM, Schmidt E, Zillikens D, et al. Analysis of serum markers of cellular immune activation in patients with bullous pemphigoid. Exp Dermatol (2017). doi:10.1111/exd.13382

147. Zebrowska A, Wagrowska-Danilewicz M, Danilewicz M, StasikowskaKanicka O, Cynkier A, Sysa-Jedrzejowska A, et al. IL-17 expression in dermatitis herpetiformis and bullous pemphigoid. Mediators Inflamm (2017) 2013:967987. doi:10.1155/2013/967987

148. Zebrowska A, Wozniacka A, Juczynska K, Ociepa K, Waszczykowska E, Szymczak I, et al. Correlation between IL36alpha and IL17 and activity of the disease in selected autoimmune blistering diseases. Mediators Inflamm (2017) 2017:8980534. doi:10.1155/2017/8980534

149. Le Jan S, Plee J, Vallerand D, Dupont A, Delanez E, Durlach A, et al. Innate immune cell-produced IL-17 sustains inflammation in bullous pemphigoid. J Invest Dermatol (2014) 134:2908-17. doi:10.1038/jid.2014.263

150. Nin-Asai R, Muro Y, Sekiya A, Sugiura K, Akiyama M. Serum thymus and activation-regulated chemokine (TARC/CCL17) levels reflect the disease activity in a patient with bullous pemphigoid. J Eur Acad Dermatol Venereol (2016) 30:327-8. doi:10.1111/jdv.12719

151. Kagami S, Kai H, Kakinuma T, Miyagaki T, Kamata M, Sugaya M, et al. High levels of CCL26 in blister fluid and sera of patients with bullous pemphigoid. J Invest Dermatol (2012) 132:249-51. doi:10.1038/jid.2011.251

152. Engmann J, Rudrich U, Behrens G, Papakonstantinou E, Gehring M, Kapp A, et al. Increased activity and apoptosis of eosinophils in blister fluids, skin and peripheral blood of patients with bullous pemphigoid. Acta Derm Venereol (2017) 97:464-71. doi:10.2340/00015555-2581

153. Riani M, Le Jan S, Plee J, Durlach A, Le Naour R, Haegeman G, et al. Bullous pemphigoid outcome is associated with CXCL10-induced matrix metalloproteinase 9 secretion from monocytes and neutrophils but not lymphocytes. J Allergy Clin Immunol (2017) 139:863-72.e3. doi:10.1016/j.jaci.2016.08.012

154. Frossi B, Mion F, Tripodo C, Colombo MP, Pucillo CE. Rheostatic functions of mast cells in the control of innate and adaptive immune responses. Trends Immunol (2017) 138:648-56. doi:10.1016/j.it.2017.04.001

155. Gunther C, Wozel G, Meurer M, Pfeiffer C. Up-regulation of CCL11 and CCL26 is associated with activated eosinophils in bullous pemphigoid. Clin Exp Immunol (2011) 166:145-53. doi:10.1111/j.1365-2249.2011.04464.x

156. Miossec P, Kolls JK. Targeting IL-17 and TH17 cells in chronic inflammation. Nat Rev Drug Discov (2012) 11:763-76. doi:10.1038/nrd3794

157. Xu Y, Chen G. Mast cell and autoimmune diseases. Mediators Inflamm (2015) 2015:246126. doi:10.1155/2015/246126

158. Furudate S, Fujimura T, Kambayashi Y, Kakizaki A, Aiba S. Comparison of CD163+ CD206+ M2 macrophages in the lesional skin of bullous pemphigoid and pemphigus vulgaris: the possible pathogenesis of bullous pemphigoid. Dermatology (2014) 229:369-78. doi:10.1159/000365946
159. Koepke J, Dresel M, Schmid S, Greulich T, Beutel B, Schmeck B, et al. Therapy with plasma purified alphal-antitrypsin (Prolastin(R)) induces time-dependent changes in plasma levels of MMP-9 and MPO. PLoS One (2015) 10:e0117497. doi:10.1371/journal.pone.0117497

160. Lin L, Bankaitis E, Heimbach L, Li N, Abrink M, Pejler G, et al. Dual targets for mouse mast cell protease- 4 in mediating tissue damage in experimental bullous pemphigoid. J Biol Chem (2011) 286:37358-67. doi:10.1074/jbc. M111.272401

161. Lin L, Betsuyaku T, Heimbach L, Li N, Rubenstein D, Shapiro SD, et al Neutrophil elastase cleaves the murine hemidesmosomal protein BP180/ type XVII collagen and generates degradation products that modulate experimental bullous pemphigoid. Matrix Biol (2012) 31:38-44. doi:10.1016/j. matbio.2011.09.003

162. Diny NL, Rose NR, Cihakova D. Eosinophils in autoimmune diseases. Front Immunol (2017) 8:484. doi:10.3389/fimmu.2017.00484

163. Simon D, Borradori L, Simon HU. Eosinophils as putative therapeutic targets in bullous pemphigoid. Exp Dermatol (2017). doi:10.1111/exd.13416

164. Tedeschi A, Marzano AV, Lorini M, Balice Y, Cugno M. Eosinophil cationic protein levels parallel coagulation activation in the blister fluid of patients with bullous pemphigoid. J Eur Acad Dermatol Venereol (2015) 29:813-7. doi:10.1111/jdv.12464

165. Bergin DA, Reeves EP, Hurley K, Wolfe R, Jameel R, Fitzgerald S, et al. The circulating proteinase inhibitor alpha-1 antitrypsin regulates neutrophil degranulation and autoimmunity. Sci Transl Med (2014) 6:217ra1. doi:10.1126/scitranslmed.3007116

166. Plee J, Le Jan S, Giustiniani J, Barbe C, Joly P, Bedane C, et al. Integrating longitudinal serum IL-17 and IL-23 follow-up, along with autoantibodies variation, contributes to predict bullous pemphigoid outcome. Sci Rep (2015) 5: 18001. doi:10.1038/srep18001

167. Taylor PR, Roy S, Leal SM Jr, Sun Y, Howell SJ, Cobb BA, et al. Activation of neutrophils by autocrine IL-17A-IL-17RC interactions during fungal infection is regulated by IL-6, IL-23, RORgammat and dectin-2. Nat Immunol (2014) 15:143-51. doi:10.1038/ni.2797

168. Liu Q, Xiao S, Xia Y. TWEAK/Fn14 activation participates in skin inflammation. Mediators Inflamm (2017) 2017:6746870. doi:10.1155/2017/6746870

169. Liu Y, Xu M, Min X, Wu K, Zhang T, Li K, et al. TWEAK/Fn14 activation participates in Ro52-mediated photosensitization in cutaneous lupus erythematosus. Front Immunol (2017) 8:651. doi:10.3389/fimmu.2017.00651

170. Peternel S, Manestar-Blazic T, Brajac I, Prpic-Massari L, Kastelan M. Expression of TWEAK in normal human skin, dermatitis and epidermal neoplasms: association with proliferation and differentiation of keratinocytes. JCutan Pathol (2011) 38:780-9. doi:10.1111/j.1600-0560.2011. 01762.x

171. Harmon A, Cornelius D, Amaral L, Paige A, Herse F, Ibrahim T, et al. IL-10 supplementation increases Tregs and decreases hypertension in the RUPP rat model of preeclampsia. Hypertens Pregnancy (2015) 34:291-306. doi:10.3109/ 10641955.2015.1032054

172. Kim N, Jeon Y-W, Nam Y-S, Lim J-Y, Im K-I, Lee E-S, et al. Therapeutic potential of low-dose IL-2 in a chronic GVHD patient by in vivo expansion of regulatory T cells. Cytokine (2016) 78:22-6. doi:10.1016/j.cyto.2015.11.020

173. Asano T, Meguri Y, Yoshioka T, Kishi Y, Iwamoto M, Nakamura M, et al. PD-1 modulates regulatory T-cell homeostasis during low-dose interleukin-2 therapy. Blood (2017) 129:2186-97. doi:10.1182/blood-2016-09-741629

174. Ma A, Yang Y, Wang Q, Wang Y, Wen J, Zhang Y. Antiinflammatory effects of oxymatrine on rheumatoid arthritis in rats via regulating the imbalance between Treg and Th17 cells. Mol Med Rep (2017) 15:3615-22. doi:10.3892/ mmr.2017.6484

175. Ettinger M, Peckl-Schmid D, Gruber C, Laimer M, Thalhamer J, Hintner H, et al. Transcutaneous gene gun delivery of hNC16A Induces BPAG2-specific tolerance. J Invest Dermatol (2012) 132:1665-71. doi:10.1038/jid.2012.19

176. Hunter Z, McCarthy DP, Yap WT, Harp CT, Getts DR, Shea LD, et al. A biodegradable nanoparticle platform for the induction of antigen-specific immune tolerance for treatment of autoimmune disease. ACS Nano (2014) 8:2148-60. doi:10.1021/nn405033r

177. Ronaghy A, Streilein RD, Hall RP III. Rituximab decreases without preference all subclasses of IgG anti-BP180 autoantibodies in refractory bullous pemphigoid (BP). J Dermatol Sci (2014) 74:93-4. doi:10.1016/j. jdermsci.2013.11.014 
178. Nguyen T, Ahmed AR. Positive clinical outcome in a patient with recalcitrant bullous pemphigoid treated with rituximab and intravenous immunoglobulin. Clin Exp Dermatol (2017) 42:516-9. doi:10.1111/ced.13092

179. De Bruyne R, Bogaert D, De Ruyck N, Lambrecht BN, Van Winckel M, Gevaert $\mathrm{P}$, et al. Calcineurin inhibitors dampen humoral immunity by acting directly on naive B cells. Clin Exp Immunol (2015) 180:542-50. doi:10.1111/ cei. 12604

180. Flynn MJ, Hartley JA. The emerging role of anti-CD25 directed therapies as both immune modulators and targeted agents in cancer. Br J Haematol (2017) 179:20-35. doi:10.1111/bjh.14770

181. Deng GM, Tsokos GC. Pathogenesis and targeted treatment of skin injury in SLE. Nat Rev Rheumatol (2015) 11:663-9. doi:10.1038/nrrheum. 2015.106

182. Genovese MC, Fleischmann RM, Greenwald M, Satterwhite J, Veenhuizen $\mathrm{M}$, Xie L, et al. Tabalumab, an anti-BAFF monoclonal antibody, in patients with active rheumatoid arthritis with an inadequate response to TNF inhibitors. Ann Rheum Dis (2013) 72:1461-8. doi:10.1136/annrheumdis2012-202775

183. Gao Q, Li Q, Xue Z, Wu P, Yang X. In vitro and in vivo evaluation of a humanized anti-APRIL antibody. Curr Mol Med (2013) 13:464-5. doi:10.2174/156652413805076867

184. Kim YG, Alvarez M, Suzuki H, Hirose S, Izui S, Tomino Y, et al. Pathogenic role of a proliferation-inducing ligand (APRIL) in murine IgA nephropathy. PLoS One (2015) 10:e137044. doi:10.1371/journal.pone.0137044

185. Björck P, Filbert E, Yang X, Trifan OC. A humanized anti-CD40 antibody with strong immune-modulatory activities capable of tumor eradication. Cancer Res (2016) 76:5004. doi:10.1158/1538-7445.AM2016-5004

186. Sondermann P. The $\mathrm{Fc} \gamma \mathrm{R} / \mathrm{IgG}$ interaction as target for the treatment of autoimmune diseases. J Clin Immunol (2016) 36:95-9. doi:10.1007/ s10875-016-0272-7

187. Biesenbach P, Kain R, Derfler K, Perkmann T, Soleiman A, Benharkou A, et al. Long-term outcome of anti-glomerular basement membrane antibody disease treated with immunoadsorption. PLoS One (2014) 9:e103568. doi:10.1371/journal.pone.0103568

188. Kasperkiewicz M, Schulze F, Meier M, van Beek N, Nitschke M, Zillikens D, et al. Treatment of bullous pemphigoid with adjuvant immunoadsorption: a case series. J Am Acad Dermatol (2014) 71:1018-20. doi:10.1016/j.jaad. 2014.06.014

189. Le Naour S, Peuvrel L, Saint-Jean M, Dreno B, Quereux G. Three new cases of bullous pemphigoid during anti-PD-1 antibody therapy. J Eur Acad Dermatol Venereol (2017). doi:10.1111/jdv.14579

190. Smith DM, Simon JK, Baker JR Jr. Applications of nanotechnology for immunology. Nat Rev Immunol (2013) 13:592-605. doi:10.1038/ nri3488

191. Huss DJ, Pellerin AF, Collette BP, Kannan AK, Peng L, Datta A, et al. Anti-CD25 monoclonal antibody Fc variants differentially impact regulatory T cells and immune homeostasis. Immunology (2016) 148:276-86. doi:10.1111/imm.12609

192. Kinnear G, Jones ND, Wood KJ. Costimulation blockade: current perspectives and implications for therapy. Transplantation (2013) 95:527-35. doi:10.1097/TP.0b013e31826d4672

193. Quintana FJ, Yeste A, Mascanfroni ID. Role and therapeutic value of dendritic cells in central nervous system autoimmunity. Cell Death Differ (2015) 22:215-24. doi:10.1038/cdd.2014.125

194. Mbongue J, Nicholas D, Firek A, Langridge W. The role of dendritic cells in tissue-specific autoimmunity.J Immunol Res (2014) 2014:857143. doi:10.1155/ 2014/857143

195. Huang J, Song G, Yin Z, He W, Zhang L, Kong W, et al. Rapid reduction of antibodies and improvement of disease activity by immunoadsorption in Chinese patients with severe systemic lupus erythematosus. Clin Rheumatol (2016) 35:2211-8. doi:10.1007/s10067-016-3354-2

Conflict of Interest Statement: The authors declare that the research was conducted in the absence of any commercial or financial relationships that could be construed as a potential conflict of interest.

Copyright (c) 2017 Liu, Li and Xia. This is an open-access article distributed under the terms of the Creative Commons Attribution License (CC BY). The use, distribution or reproduction in other forums is permitted, provided the original author(s) or licensor are credited and that the original publication in this journal is cited, in accordance with accepted academic practice. No use, distribution or reproduction is permitted which does not comply with these terms. 